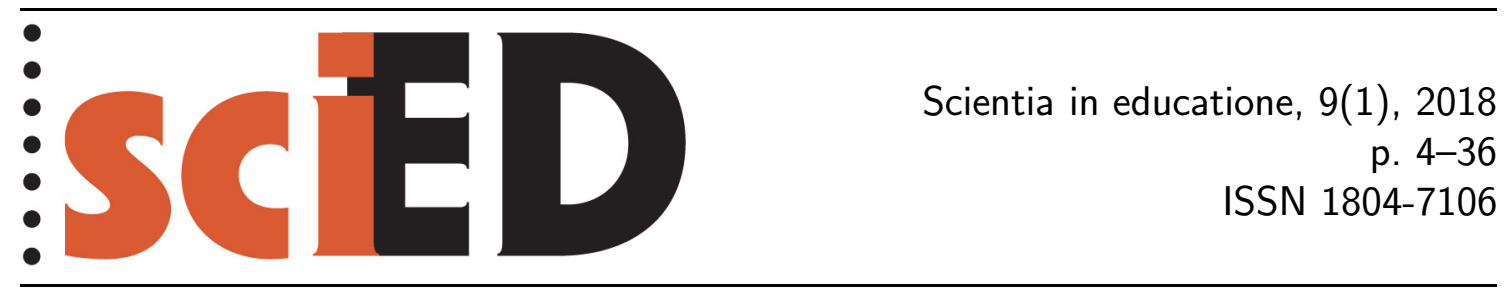

\title{
Analýza tématu řasy ve vybraných učebnicích přírodopisu
}

\author{
Blažena Brabcová, Libuše Vodová, Kateřina Hvězdová
}

\begin{abstract}
Abstrakt
Studie je zaměřena na zpracování tématu Řasy v osmi učebnicích přírodopisu. Cílem výzkumu bylo zjistit odborné nedostatky v učivu o řasách. Metodou výzkumu byla obsahová analýza (Gavora, 2010, 2015). Zjištěné nedostatky byly rozděleny na dvě kategorie - nedostatky týkající se zařazení řas do systému a další odborné nedostatky. Celkem byly v učebnicích zjištěny 4 typy nedostatků v systematickém zařazení řas a 61 dalších odborných nedostatků. V diskusi jsou porovnány výsledky studie se zjištěními jiných autorů a vyvozovány dopady na vzdělávání žáků. Článek je doplněn přílohou s uvedením odborné správnosti determinovaných chyb.
\end{abstract}

Klíčová slova: učebnice přírodopisu, řasy, obsahová analýza, odborné chyby.

\section{Analysis of Topic Algae in Selected Natural History Textbooks}

\begin{abstract}
The study explored the way in which the topic Algae was presented in eight Natural History textbooks. The aim of the research was to find professional flaws in the curriculum dealing with Algae. The study deployed the content analysis method (Gavora, 2010, 2015). The identified flaws were divided into two categories - misclassification of Algae within the system of organisms and other professional flaws. These study identified 4 types of misclassification of Algae within the system of organisms and 61 other professional mistakes in total. The subsequent discussion compares the results of this study with the findings of other authors. The resulting synthesis is used by way of identifying the potential impact of the misinformation on the education of pupils. The article is supplemented by an appendix detailing the professional accuracy of the identified mistakes.
\end{abstract}

Key words: Natural History textbooks, algae, content analysis, professional mistakes. 
V rámci vzdělávacího obsahu každého z předmětů vyučovaných na základní škole lze rozlišit učivo, jehož význam je sice velký, ale v kontextu ostatního učiva mu nelze v současných učebnicích věnovat větší prostor. V rámci vzdělávacího oboru př́rodopis lze, podle našeho mínění, za takové učivo označit učivo o řasách, které má značný environmentální význam. Transformace algologických poznatků do podoby srozumitelné žákům základních škol a zároveň prezentovatelné v omezeném prostoru učebnice je náročná a může během ní docházet $\mathrm{k}$ nepřesnostem či chybám. K odhalení těchto nedostatků jsou třeba nejen odborné znalosti, ale i praktické zkušenosti z oboru. Lze tedy předpokládat, že uživatelé učebnic z řad učitelů nebudou schopni řadu z nich rozpoznat a opravit do podoby, která je v souladu se současným vědeckým poznáním. V tomto článku je poukazováno na konkrétní nedostatky v učivu o řasách v aktuálně používaných učebnicích př́írodopisu pro ZŠ a nižŠí stupně víceletých gymnázií. Cílem výzkumu bylo tyto nedostatky identifikovat a objasnit jejich podstatu. Pro výzkum byla zvolena metoda obsahové analýzy (Gavora, 2010, 2015).

\section{TEORETICKÁ VÝCHODISKA}

\subsection{DidAKTICKÁ TRANSFORMACE}

Učebnice patří mezi jedny z nejpoužívanějších materiálních prostředků výuky, přičemž učiteli jsou využíány zejména během plánování výuky (Mikk, 2007; Nogová, 2008; Průcha, 2009), žáky pak při vlastní realizaci výuky (Nogová, 2008; Cervenková, 2011) a také během domácí přípravy. S ohledem na fakt, že jsou učebnice jako tzv. edukační konstrukty záměrně vytvářeny pro potřeby edukace (Průcha, 1998), vyvstává již při jejich tvorbě otázka, jakým zpơsobem transformovat velké množství vědeckých poznatků ve vzdělávací obsah, který by byl přiměřený věku a znalostem žáků. Protože přímý transfer vzdělávacího obsahu z vědeckých disciplín do vyučovacích předmětů není možný, je třeba jej didakticky transformovat, přičemž vyučovaný obsah pak nelze chápat jako zjednodušené, redukované a degradované poznání, ale poznání rekonstruované a specifické (Skalková, 2006). Zároveň je třeba, aby i po didaktické transformaci zůstalo pojetí vyučovacího předmětu v souladu se soudobým pojetím dané výchozí disciplíny (Skalková, 2006). Didaktická transformace v další úrovni pokračuje vlastní realizací výuky, která je uskutečňována řadou kroků v činnosti učitele (Skalková, 2007). Celý proces didaktické transformace pak Möhlenbrock definuje jako: Přenesení daného, z didaktického hlediska pečlivě vybraného vědeckého obsahu (transformadum), do podoby zjednodušeného a pro žáky srozumitelného vzdělávacího obsahu (transformát), s přihlédnutím k receptivním a kognitivním vlastnostem žáka i vzdělávacím cílům vztažených k tomuto vzdělávacímu obsahu. (citováno v překladu Knechta, 2007: s. 73)

\section{2 $\check{R}$ ASY A JEJICH POSTAVENÍ V KURIKULÁRNÍCH DOKUMENTECH}

Řasy jsou převážně fototrofní organismy a patří ve sladkých i mořských vodách k největším primárním producentům organické hmoty (Kalina \& Váňa, 2005). Na přitomnosti řas a jejich produktivitě závisí řetězec konzumentů a destruentů organické hmoty (Kalina \& Váňa, 2005). Řasy tvoří také součást mnoha lišejníků, které díky svému pionýrskému výskytu na stanovištích působí jako půdotvorní činitelé 
(Kalina \& Váňa, 2005). Kromě významného postavení řas v př́rodě, jsou řasy také využívány v různých oblastech lidské činnosti (Kalina \& Váňa, 2005).

Algologie jako věda o řasách pracuje zejména s mikroskopickými organismy, které jsou pro žáky těžko představitelné. Pro učitele je toto těžko uchopitelné téma komplikováno navíc tím, že řasy jsou systematicky řazeny do různých říší/skupin organismů.

Systematické zařazení některých skupin řas (ale i rodů nebo druhů) se v poslední době, díky molekulárním analýzám buněk, často mění. V systému organismů se také objevují návrhy na změny systematických jednotek na vyšší úrovni, např. počet říší a přiřazení organismů k nim (např. Baldauf et al., 2000; Simpson \& Roger, 2004; Keeling et al., 2009). Role učebnice je v tomto směru ztížena, protože na častější změny nemohou učebnice reagovat.

V platných kurikulárních dokumentech je řasové problematice věnováno málo prostoru. Vzhledem ke svému obrovskému významu, zejména ve vodních ekosystémech a v biochemickém koloběhu látek na Zemi (Kalina \& Váňa, 2005), by si podle nás řasy zasloužily více prostoru.

Analýzou zastoupení tématu řasy v Rámcovém vzdělávacím programu pro základní vzdělávání (dále jen RVP ZV), který je východiskem pro tvorbu Školních vzdělávacích programů pro základní školy, je možno zjistit, že samotný pojem řasy se v něm objevuje pouze dvakrát. Řasy jsou v RVP ZV (2016) zmiňovány v rámci vzdělávacího oboru Přírodopis - u učiva tematického celku Biologie rostlin věnovaného systému rostlin je zmíněno „poznávání a zařazování daných zástupců běžných druhů řas. . " a také v rámci průřezového tématu Environmentální výchova - v tematickém okruhu Ekosystémy a tématu moře se objevuje pojem „mořské řasy“. Ke stejným závěrům došly ve své publikaci Kaufnerová a Vágnerová (2013). Na základě podrobnějšího studia výše uvedeného dokumentu předpokládáme, že řasy budou zmiňovány i při probírání učiva náležícího do dalších tematických celků vzdělávacího oboru Př́rodopis (např. Obecná biologie a genetika: základní struktura života, význam a zásady tř́iění organismů; Biologie hub: lišejníky; Základy ekologie: organismy a prostředí) a tematických okruhů průřezového tématu Environmentální výchova (Základní podmínky života: voda).

Také v mnohých učebnicích pro ZŠ není význam řas dostatečně zdůrazněn (podobně se vyjadřují též Kaufnerová \& Vágnerová, 2013). V některých z nich nejsou do učiva vůbec zahrnuty rozsivky, přičemž se jedná u nás o druhově a početně nejhojnější zástupce řas a podle Kaštovského a Hauera (2017c) jsou rozsivky patrně nejpočetnějšími vodními eukaryotickými organismy.

\section{CÍle vÝZKumu A VÝZKUMNÉ OTÁZKY}

Cílem výzkumu bylo zjistit nedostatky ve zpracování učiva o řasách v učebnicích přírodopisu pro ZS̆. Za tímto účelem byly formulovány následující výzkumné otázky:

1. Je učivo o řasách ve vybraných učebnicích přírodopisu pojato systematicky nebo ekologicky? Do které kapitoly je zařazeno? Obsahuje zpracování učiva o řasách otázky, úkoly a shrnutí?

2. Jakým způsobem je ve vybraných učebnicích řešeno začlenění řas do systému organismů?

3. Jaké odborné nedostatky se v učivu o řasách ve vybraných učebnicích objevují?

4. Mají odborné nedostatky nějaké společné znaky? Lze na základě společných znaků klasifikovat nedostatky do skupin? 


\section{Metodika}

Výzkum vychází z analýzy zpracování učiva o řasách v osmi vybraných učebnicích přírodopisu pro základní školy a nižší stupeň víceletých gymnázií (viz tab. 1) ze sedmi nakladatelství. Do analyzovaného souboru učebnic byly zařazeny ty, které prezentují učivo o řasách a zároveň jsou podle autorek na školách hojně použivány. K některým analyzovaným učebnicím existují v současné době i novější vydání, použita však byla ta, která jsou na základních školách v převaze, nebot jejich obnova na školách je dlouhodobou záležitostí. Všechny učebnice obsahovaly, a některé dodnes obsahují, doložku MŠMT (Ministerstva školství, mládeže a tělovýchovy).

Látka vztahující se k řasám je ve většině analyzovaných učebnic obsažena v učebnicích přírodopisu pro šestý ročník základní školy. Výjimku tvoří pouze 2. díl učebnice př́rodopisu pro 7. ročník z nakladatelství Nová škola (Hedbávná, 2008). U všech učebnic byla analyzována jak verbální (např. výkladový text, otázky a úkoly), tak obrazová složka (např. ilustrace a fotografie). Pracovní sešity a metodické př́ručky k učebnicím nebyly prozatím analýze podrobeny.

Při vlastním výzkumu byl nejprve stanoven cíl výzkumu a definovány výzkumné otázky (viz oddíl 2).

Pro zkoumání obsahových vlastností učebnic přírodopisu s důrazem na nedostatky učebnic spojené s didaktickou transformací vědeckých poznatků z algologie, byla v našem výzkumu zvolena metoda obsahové analýzy. Základní postup analýzy byl zvolen podle Gavory (2010). Kritéria, která musí obsahová analýza splňovat, rovněž vycházejí z Gavory (2015).

Zkoumán byl tzv. věcný obsah učebnic, který se vztahuje k odbornému zdroji učiva (Průcha, 1998). Analýza textu se v souladu s výzkumnými otázkami zaměřila na odraz stavu vědeckého poznání v učebnicích. Během výzkumu byly používány metody kvalitativního i kvantitativního výzkumu tak, jak je uvádí Hendl (2005: s. $45-59)$.

Tab. 1: Seznam analyzovaných učebnic př́rodopisu

Cabradová, V., Hasch, F., Sejpka, J. \& Vaněčková, I. (2003). Př́rodopis pro

6. ročník základni školy a primu víceletého gymnázia. Plzeň: Fraus.

Černík, V., Hamerská, M., Martinec, Z. \& Vaněk, J. (2007). Přírodopis 6 pro

základní školy, zoologie a botanika. Praha: SPN.

Dobroruka, L. J., Cílek, V., Hasch, F. \& Storchová, Z. (1999). Přírodopis I pro

6. ročník $Z \breve{S}$. Praha: Scientia.

Hedbávná, H. (2008). Př́rodopis 2. díl: Botanika. Brno: Nová škola.

Jurčák, J. \& Froněk, J. (2004). Př́rodopis 6 pro základni školy, zoologie

a botanika. Olomouc: Prodos.

Kvasničková, D., Jeník, J., Pecina, P., Froněk, J. \& Cais, J. (2002). Ekologický

př́rodopis pro 6. ročník základni školy a nižši ročníky víceletých gymnázii. Praha:

Fortuna.

Maleninský, M., Smrž, J. \& Škoda, B. (2004). Přírodopis pro 6. ročník, Botanika 1, Zoologie 1. Praha: Nakladatelství České geografické společnosti.

Musilová, E. \& Konětopský, A. (2007). Př́rodopis 1. díl: Úvod do učiva př́rodopisu. Brno: Nová škola. 
U zkoumaného materiálu byly zaznamenávány odborné nedostatky identifikované ve verbálních i obrazových komponentech tak, aby bylo umožněno jejich další zpracování. V průběhu analýzy bylo třeba přihlížet také $\mathrm{k}$ uspořádání, návaznosti a smysluplnosti textu. Zjištěné odborné nedostatky byly následně ověřovány a konfrontovány s vědeckými poznatky. Teprve po prvotní analýze byly stanoveny konkrétní analytické kategorie a podkategorie (definice viz Hendl, 2005). Kategoriální systém byl definován tak, aby šlo zjištěné nedostatky jednoznačně zařadit do některé z podkategorií (Hendl, 2005) a zároveň, aby se jednotlivé podkategorie vzájemně nepřekrývaly (Gavora, 2010). Celkem bylo stanoveno devět podkategorií, náležících ke dvěma základním kategoriím charakterizujícím nedostatky z odborného hlediska. Do první kategorie, týkající se systematického třídění organismů na Zemi, spadají čtyři podkategorie nedostatků $1 \mathrm{~A}$ až 1D. Druhá kategorie pak zahrnuje všechna další chybná odborná tvrzení či pojmy. Tyto podkategorie byly pro potřeby výzkumu označeny $2 \mathrm{~A}$ až $2 \mathrm{E}$. Označení podkategorií a jejich přesné vymezení přináší tab. 2. Odborné nedostatky nalezené $\mathrm{v}$ analyzovaných učebnicích byly následně klasifikovány do výše uvedených kategorií a podkategorií. U nedostatků týkajících se systematického tř́iění organismů byla zaznamenávána jejich pouhá presence/absence v dané učebnici, zatímco výskyt všech dalších odborných nedostatků podkategorií $2 \mathrm{~A}$ až $2 \mathrm{E}$ byl již pro jednotlivé učebnice kvantifikován.

Tab. 2: Vymezení kategorií a podkategorií pro přiřazení nedostatku zjištěného $\mathrm{v}$ učebnicích

\begin{tabular}{|c|c|c|}
\hline $\begin{array}{c}\text { Označení } \\
\text { podkategorie }\end{array}$ & $\begin{array}{l}\text { Zkrácená } \\
\text { charakteristika }\end{array}$ & Přesné vymezení podkategorie \\
\hline \multicolumn{3}{|c|}{ Kategorie - nedostatky v systému } \\
\hline $1 \mathrm{~A}$ & systém/rostliny & chybné zařazení některých řas do říše Plantae (rostliny) \\
\hline $1 \mathrm{~B}$ & $\begin{array}{l}\text { záměna } \\
\text { oddělení }\end{array}$ & $\begin{array}{l}\text { chybné zařazení některých řas do nižší systematické } \\
\text { jednotky (oddělení) }\end{array}$ \\
\hline $1 \mathrm{C}$ & nižší rostliny & chybné zařazení řas do zastaralé skupiny nižších rostlin \\
\hline $1 \mathrm{D}$ & sinice/rostliny & chybné zařazení sinic do ř́̌še Plantae (rostliny) \\
\hline \multicolumn{3}{|c|}{ Kategorie - další odborné nedostatky } \\
\hline $2 \mathrm{~A}$ & $\begin{array}{l}\text { nesprávný } \\
\text { odborný } \\
\text { termín }\end{array}$ & $\begin{array}{l}\text { chyba je v použití nesprávného odborného termínu, pro } \\
\text { odstranění nedostatku by stačilo termín nahradit } \\
\text { správným výrazem }\end{array}$ \\
\hline $2 \mathrm{~B}$ & $\begin{array}{l}\text { nesprávné } \\
\text { tvrzení }\end{array}$ & $\begin{array}{l}\text { celé tvrzení je odborně chybné; text/věta obsahuje více } \\
\text { chybných výrazů a spojení; nedostatek není možné } \\
\text { odstranit pouze výměnou chybného termínu za správný, } \\
\text { bylo by třeba celé tvrzení přeformulovat }\end{array}$ \\
\hline $2 \mathrm{C}$ & neúplný výčet & $\begin{array}{l}\text { tvrzení v textu obsažená jsou sice správná, ale ne } \\
\text { úplná, a to kvưli absenci typických možností; uvedené } \\
\text { možnosti nepodávají úplnou charakteristiku jevu, což } \\
\text { by mohlo vést k vytvoření mylných představ čtenáře }\end{array}$ \\
\hline $2 \mathrm{D}$ & nepřesné & $\begin{array}{l}\text { tvrzení obsažená v učebnici jsou nepřesná a to různými } \\
\text { způsoby: tvrzení nelze ověřit; problematika je nevhodně } \\
\text { zjednodušena; organismy jsou chybně znázorněny; } \\
\text { návody na činnosti žáků jsou nepřesné }\end{array}$ \\
\hline $2 \mathrm{E}$ & ostatní & $\begin{array}{l}\text { kategorie zahrnuje nedostatky, které nespadají do } \\
\text { žádné z výše uvedených kategorií, ale přesto je potřeba } \\
\text { je vyhodnotit }\end{array}$ \\
\hline
\end{tabular}


Pro vyhodnocení aktuálního zařazení řas do systému organismů na podkladě vědeckých poznatků byly využity poslední vydaná vysokoškolská učebnice v českém jazyce (Kalina \& Váňa, 2005) a publikace od Adla et al. (2012). Kalina a Váňa (2005) vychází ze systému Cavalier-Smitha (1998). Adl et al. (2012) předkládají nejmodernější pohled na systematické zařazení organismů. Vysokoškolská učebnice Kalina a Váňa (2005) je jedinou tištěnou publikací v českém jazyce, která zahrnuje systematické třídění řas a jejich začlenění do systému organismů. Neobsahuje vědecky nejaktuálnější systém organismů, který lze nalézt v (Adl et al., 2012) nebo též v (Keeling et al., 2009). Důvodů, proč bylo systematické zařazení řas konfrontováno také s učebnicí Kaliny a Váni (2005) a nejen s nejnovějším systémem (Adl et al. 2012), je několik: systém organismů v učebnicích přírodopisu je zjednodušený a ani u ostatních organismů nereflektuje současné vědecké poznatky v třídění organismů, stačí tedy poukázat na vyčlenění některých řas z říše rostliny, což splňují oba systémy. Nejnovější systém organismů není ve výuce vysokoškolských studentů učitelů zatím všude rozšǐren. Účelem publikace je nejen na chyby poukázat, ale měla by také být návodem pro učitele př́rodopisu základních škol, kteří s učebnicemi pracují. Srovnání s česky psanou publikací bude pro ně lépe akceptovatelné. V př́lohách, popisujících přesně chyby $\mathrm{v}$ systematickém zařazení řas $\mathrm{v}$ jednotlivých učebnicích, je pak poznamenáno i nejnovější zařazení řas mezi organismy s nově vytvořeným systémem organismů podle Adla et al. (2012).

Chybnými odbornými tvrzeními či pojmy se rozumí taková, která nejsou v souladu se současnými vědeckými výzkumy či odbornými poznatky. Odborné informace uvedené $\mathrm{v}$ učebnicích byly konfrontovány s vědeckými poznatky $\mathrm{z}$ algologie a hydrobiologie. Uplatňovány byly ale také poznatky z jiných oborů. Pro ověřování byla nejdůležitějším zdrojem vysokoškolská učebnice (Kalina \& Váňa (2005). Dále byly využívány aktuální webové stránky ${ }^{1}$ (Kaštovský \& Hauer, 2017a), které slouží ke vzdělávacím účelům nejen studentům vysokých škol, ale též odborníkům v algologii. Stránky jsou neustále aktualizovány našimi předními odborníky v algologii z Jihočeské univerzity v Českých Budějovicích, J. Kaštovským a T. Hauerem. Sporná tvrzení byla dále ověřována $\mathrm{v}$ algologické literatuře, př́padně $\mathrm{v}$ dalších odborných textech. Nedostatky v systematickém zařazení v publikacích (Cavalier-Smith, 1981, 1986, 1998, Rosypal et al., 1992). Další odborné nedostatky v publikacích (Cyrus \& Hindák, 1978; Hindák, 1978; Ettl, 1983, Ambrozová, 1999; Knox, 2000; Granéli \& Turner, 2002; Víden, 2005; Nedbalová \& Lukavský, 2007; Šmarda, 2009; Lukavský, 2014; Vrtiška, 2014; Guiry \& Guiry, 2017a; Kaštovský \& Hauer, 2017a). Některá tvrzení také posuzovala spoluautorka článku B. Brabcová (z Pedagogické fakulty Masarykovy univerzity) na základě svých bohatých zkušeností v algologii. Některé odborné poznatky byly diskutovány s algologickým odborníkem P. Marvanem (Botanický ústav AVČR, Přrirodovědecká fakulta MU).

\section{VÝSLEDKY}

\subsection{PřEHLED USPOŘÁdÁNí UČIVA O ŘASÁCH}

Z osmi analyzovaných učebnic prŕrodopisu bylo učivo pojato ekologicky pouze v učebnici z nakladatelství Fortuna (Kvasničková et al., 2002). Šest učebnic mělo systematické pojetí učiva: učebnice z nakladatelství Scientia (Dobroruka et al., 1999), Fraus (Čabradová et al., 2003), Prodos (Jurčák \& Froněk, 2004), Nakladatelství

\footnotetext{
${ }^{1}$ Dostupné z www.sinicearasy.cz
} 
České geografické společnosti (Maleninský et al., 2004; dále jen Nakladatelství C̆GS), SPN (Černík et al., 2007), Nová škola (Musilová \& Konětopský, 2007). V jedné učebnici (učebnice z nakladatelství Nová škola, Hedbávná, 2008) byly oba př́istupy kombinovány. Přehled uspořádání učiva o řasách v jednotlivých učebnicích ukazuje tab. 3. Ve všech případech jsou řasy $\mathrm{v}$ učebnicích řazeny mezi rostliny do kapitol s různými názvy. Všechny učebnice mají na závěr učiva o řasách uvedeny úkoly pro žáky. V pěti učebnicích jsou na konci učiva uvedeny také otázky, čtyři mají na závěr shrnutí.

\subsection{ZAČLENĚNÍ ŘAS DO SYSTÉMU ORGANISMŮ}

Všechny organismy označované jako řasy jsou podle Kaliny a Váni (2005) řazeny do tř́i ř́rśí organismů: Protozoa, Chromista a Plantae, podle Adla et al. (2012) do několika skupin: Skupiny „nejasného postavení“, SAR skupina, Archaeplastida a Excavata. Všechny skupiny řas uváděné v učebnicích, zjednodušeně hnědé řasy, červené řasy a zelené řasy, řazené autory učebnic do rostlin do této skupiny, tedy říše Plantae, nepatří (viz podkategorie 1A). Jako hnědé řasy jsou ve většině učebnic značeny chaluhy, někdy též rozsivky. Obě skupiny řas řadí Kalina a Váňa (2005) do říše Chromista, Adl et al. (2012) do Stramenopila skupiny SAR. Chaluhy jsou mezi rostliny řazeny v učebnicích z nakladatelství Fraus (Čabradová et al., 2003), SPN (Černík et al., 2007), Scientia (Dobroruka et al., 1999) a Nová škola (Hedbávná, 2008). Rozsivky pak mezi rostliny řadí učebnice z nakladatelství SPN (Černík et al., 2007), Scientia (Dobroruka et al., 1999) a Prodos (Jurčák \& Froněk, 2004). V učebnici nakladatelství Scientia (Dobroruka et al., 1999) je do rostlin řazen Dinobryon (viz obrázek na s. 52, bez pojmenování taxonu), který patří mezi zlativky, tedy také do ř́šse Chromista (Kalina \& Váňa, 2005) či podskupiny Alveolata SAR skupiny (podle Adl et al., 2012). Krásnoočka, řazená mezi rostliny v učebnicích nakladatelství Fraus (Čabradová et al., 2003), SPN (Černík et al., 2007), Scientia (Dobroruka et al., 1999), Prodos (Jurčák \& Froněk, 2004) a Ceratium v učebnici nakladatelství Scientia (Dobroruka et al., 1999: obr. na s. 52 bez pojmenování), náleží do ř́še Protozoa (Kalina \& Váňa, 2005), podle Adla et al. (2012) krásnoočko do skupiny Excavata a Ceratium do Alveolata skupiny SAR. Tyto řasy nebyly řazeny k rostlinám ani podle staršího systému Cavalier-Smitha (1998).

V učebnici nakladatelství Scientia (Dobroruka et al., 1999) je krásnoočko, kromě chybného zařazení mezi rostliny, ještě zařazeno k prvokům, což je podle Kaliny a Váni (2005) správné.

V učebnici z nakladatelství Fraus (Čabradová et al., 2003) je šroubatka řazena do zelených řas, což odpovídá oddělení Chlorophyta (zelené řasy), ale patřxí do oddělení Charophyta (chary) (Kalina \& Váňa, 2005).

V učebnicích z nakladatelství Fraus (Čabradová et al., 2003), Scientia (Dobroruka et al., 1999) a Prodos (Jurčák \& Froněk, 2004) jsou řasy označovány za tzv. nižší rostliny. Nižší rostliny byly dříve na úrovni podříše a zahrnovaly kromě řas také houby a lišejníky (např. Rosypal, 1992). Toto systematické třídění organismů se ale již dlouhou dobu nepouživá (viz Cavalier-Smith, 1981).

Za chybu považují autorky zařazení sinic do kapitol Jednobuněčné rostliny a Rostliny mnohobuněčné v učebnici nakladatelství Prodos (Jurčák \& Froněk, 2004). Sinice jsou jako prokaryotické organismy řazeny do říše Bacteria (Kalina \& Váňa, 2005).

Všechny učebnice řadí řasy v systému organismů mezi rostliny. Podle systému třídění organismů, se kterými byly výsledky výzkumu porovnávány (Kalina \& Váňa, 
Tab. 3: Přehled uspořádání učiva o řasách ve vybraných učebnicích přírodopisu

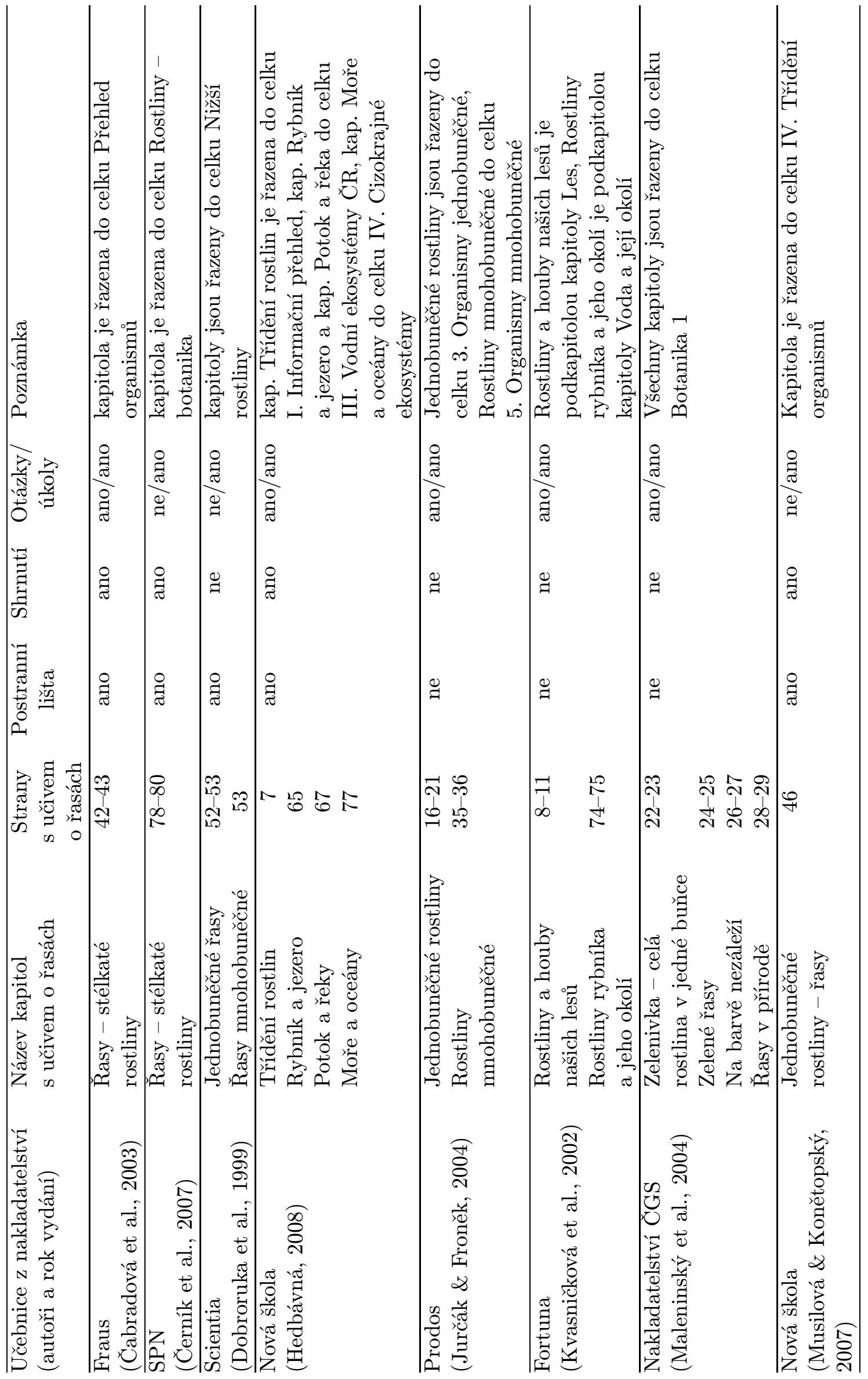


2005; Adl et al., 2012), patř́ mezi rostliny jen červené řasy (Rhodophyta) a zelené řasy (Chlorophyta). Zástupci jiných skupin řas uváděných v učebnicích mezi rostliny nepatří. Přehled výskytu nedostatků v zařazení řas do systému organismů v učebnicích přináší tab. 4.

Tab. 4: Nedostatky v zařazení řas do systému organismů v učebnicích v jednotlivých analytických podkategoriích, $\times$ znamená výskyt nedostatku v učebnici

\begin{tabular}{lcccc}
\hline & \multicolumn{4}{c}{ Analytická podkategorie } \\
\hline Učebnice & 1A & 1B & $1 \mathrm{C}$ & $1 \mathrm{D}$ \\
\hline Fraus (Cabradová et al., 2003) & systém/ & záměna & nižší & sinice/ \\
rostliny & oddělení & rostliny & rostliny \\
\hline SPN (Černík et al., 2007) & $\times$ & $\times$ & $\times$ & - \\
\hline Scientia (Dobroruka et al., 1999) & $\times$ & - & - & - \\
\hline Nová škola (Hedbávná, 2008) & $\times$ & - & $\times$ & - \\
\hline Prodos (Jurčák \& Froněk, 2004) & $\times$ & - & - & - \\
\hline Fortuna (Kvasničková et al., 2002) & $\times$ & - & $\times$ & $\times$ \\
\hline Nakl. ČGS (Maleninský et al., 2004) & $\times$ & - & - & - \\
\hline Nová škola (Musilová \& Konětopský, 2007) & $\times$ & - & - & - \\
\hline
\end{tabular}

\subsection{OdBORNÉ NEDOSTATKY V UČIVU O ŘASÁCH}

\subsubsection{DRUHY ODBORNÝCH NEDOSTATKU}

Celkem bylo v osmi vybraných učebnicích zjištěno 61 odborných nedostatků v učivu o řasách. Nedostatky byly různého druhu, týkaly se verbálních i obrazových komponent učiva. Nejhojnějšími chybami byly jednoznačně ty, kdy celá tvrzení o řasách byla chybná, tzv. nesprávná tvrzení. Většinou se tato tvrzení týkala výskytu řas a také jejich vyobrazení. Nepřesnosti v textu nebo vyobrazení, použití nesprávného odborného termínu i neúplný výčet možností v tvrzení o řasách měly, co do počtu výskytu v analyzovaných učebnicích, srovnatelnou úroveň. Z těchto chyb stojí za zmínku použití výrazu kolonie pro cenobium váleče $\mathrm{v}$ každé $\mathrm{z}$ analyzovaných učebnic. Napříč všemi kategoriemi chyb se objevují nedostatky týkající se vyobrazení stélek řas. Konkrétní zjištěné odborné nedostatky jsou uvedeny dále v textu a podrobně, včetně nápravy, v př́loze.

\subsubsection{SPOLEČNÉ ZNAKY}

Odborné nedostatky byly navzájem porovnány za účelem zjištění možných společných znaků a jejich př́padného vymezení. Při porovnávání odborných nedostatků byla pozornost věnována zejména jejich podstatě a možnosti opravy na správná tvrzení. Výsledkem bylo rozlišení čtyř podkategorií odborných nedostatků s dobře rozlišitelnými typickými vlastnostmi a jedna podkategorie zahrnující nedostatky, které nebylo možno zařadit do žádné z předchozích. Společnými znaky nedostatků byly: nesprávný odborný termín, chybné celé odborné tvrzení, neúplné tvrzení s absencí typických možností a nepřesné tvrzení. 


\subsubsection{KLASIFIKACE NEDOSTATKU}

Klasifikaci odborných nedostatků a jejich výskyt v jednotlivých učebnicích uvádí tab. 5 a obr. 1.

Tab. 5: Počet chybných odborných nedostatků v učivu o řasách (jiných než systematických)

\begin{tabular}{lccccc}
\hline & \multicolumn{5}{c}{ Analytická podkategorie } \\
& $2 \mathrm{~A}$ & $2 \mathrm{~B}$ & $2 \mathrm{C}$ & $2 \mathrm{D}$ & $2 \mathrm{E}$ \\
\hline Učebnice & $\begin{array}{c}\text { nesprávný } \\
\text { odb. termín }\end{array}$ & $\begin{array}{c}\text { nesprávné } \\
\text { tvrzení }\end{array}$ & $\begin{array}{c}\text { neúplný } \\
\text { výčet }\end{array}$ & nepřesnost & ostatní \\
\hline $\begin{array}{l}\text { Fraus } \\
\text { (Čabradová et al., 2003) }\end{array}$ & 2 & 0 & 3 & 4 & 0 \\
\hline $\begin{array}{l}\text { SPN } \\
(\text { Cerník et al., 2007) }\end{array}$ & 1 & 3 & 0 & 0 & 1 \\
\hline $\begin{array}{l}\text { Scientia } \\
\text { (Dobroruka et al., 1999) }\end{array}$ & 1 & 1 & 1 & 3 & 1 \\
\hline $\begin{array}{l}\text { Nová škola } \\
\text { (Hedbávná, 2008) }\end{array}$ & 2 & 0 & 1 & 0 & 0 \\
\hline $\begin{array}{l}\text { Prodos } \\
\text { (Jurčák \& Froněk, 2004) }\end{array}$ & 3 & 14 & 2 & 3 & 1 \\
\hline $\begin{array}{l}\text { Fortuna } \\
\text { (Kvasničková et al., 2002) }\end{array}$ & 1 & 1 & 1 & 1 & 0 \\
\hline $\begin{array}{l}\text { Nakl. ČGS } \\
\text { (Maleninský et al., 2004) }\end{array}$ & 1 & 3 & 1 & 1 & 0 \\
\hline $\begin{array}{l}\text { Nová škola } \\
\text { (Musilová \& Konětopský, 2007) }\end{array}$ & 0 & 1 & 1 & 2 & 0 \\
\hline \begin{tabular}{l} 
Celkem \\
\hline
\end{tabular} & 11 & 23 & 10 & 14 & 3 \\
\hline
\end{tabular}

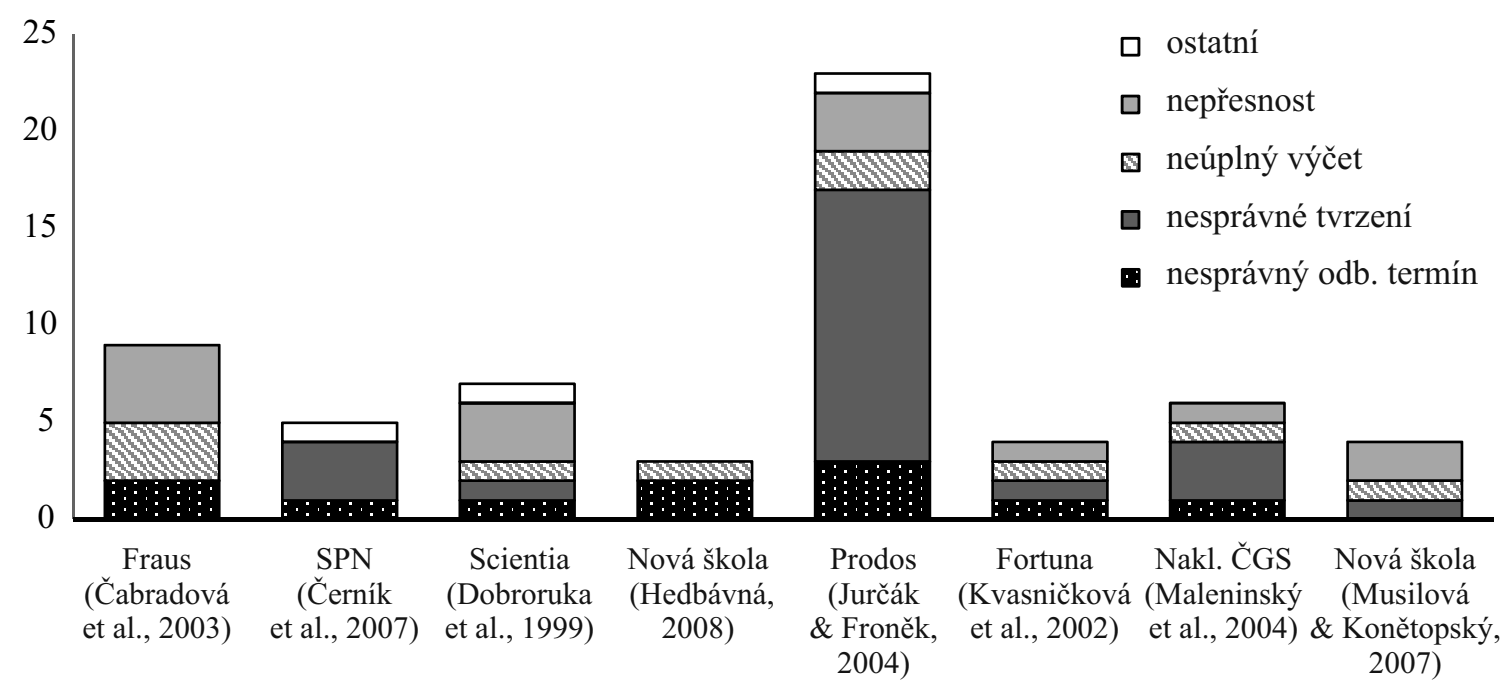

Obr. 1: Grafické znázornění počtu odborných nedostatků v učivu o řasách (jiných než systematických) 


\section{A NESPRÁVNÝ ODBORNÝ TERMÍN}

Odborný nedostatek v podobě nesprávně použitého odborného termínu (podkategorie $2 \mathrm{~A})$ se vyskytoval v analyzovaných učebnicích v jedenácti př́padech $(18,0 \%$ ze všech nedostatků). Nejčastěji se opakujícím nedostatkem, vyskytujícím se v šesti z osmi analyzovaných učebnic (s výjimkou učebnic z nakladatelství Fortuna (Kvasničková et al., 2002) a Nová škola (Musilová \& Konětopský, 2007)), bylo nepřesné pojmenování pro cenobium váleče. Další nesprávné odborné termíny se vykytují v učebnici nakladatelství Prodos (Jurčák \& Froněk, 2004), a to ve schématu rozmnožování kadeřnatky a obsahu aerotopů sinic, v učebnici nakladatelství Fraus (Čabradová et al., 2003) pak v souvislosti s vláknitými koloniemi šroubatky a žabího vlasu. U učebnice z nakladatelství Nová škola (Hedbávná, 2008: s. 77) se nesprávný termín objevuje ve tvrzení „Mnohobuněčné řasy koření na dně“. V další učebnici téhož nakladatelství (Musilová \& Konětopský, 2007) nebyla nalezena žádná chyba v odborném termínu.

\section{B NESPRÁVNÉ TVRZENÍ}

Ke kategorii 2B nesprávné tvrzení náleží nejvyšší počet oborných nedostatků, a to 23 nedostatků (37,7 \% ze všech zjištěných nedostatků). Nejvyšší počet nedostatků byl zjištěn v učebnici nakladatelství Prodos (Jurčák \& Froněk, 2004), ve které bylo v odborném zpracování učiva o řasách zjištěno celkem 23 nedostatků $(37,7$ \% z nedostatků všech učebnic). Právě tato učebnice se nejvíce podílela na vysokém počtu nedostatků v podkategorii $2 \mathrm{~B}$ - nesprávné tvrzení. Zároveň jsou nesprávná tvrzení nejčastější chybou vyskytující se v učebnici z nakladatelství Prodos (Jurčák \& Froněk, 2004) a představují 60,9 \% veškerých nedostatků této učebnice.

Chyby uvedené ve výše citované učebnici se v této podkategorii týkají zobrazení řas (zrněnka, pláštěnka a zelenivka na obr. nejsou, i když je popisek uvádí) a popisu stavby stélky (krásnoočko štíhlé má 1-2 bičíky). Dále doby rozmnožování šroubatky, výskytu rozsivek v planktonu a uplatnění rozsivek a šroubatky v potravním řetězci. Učebnice nakladatelství SPN (Černík et al., 2007) a Nakladatelství ČGS (Maleninský et al., 2004) obsahují po třech zjištěných nesprávných tvrzeních. U prvně zmiňované učebnice (Cerník et al., 2007) se jedná o chyby v zobrazení žabího vlasu, výskytu žabího vlasu a znaků systematického zařazení řas, u druhé (Maleninský et al., 2004) se dvakrát objevuje chyba ve výskytu zelenivky a jednou v popisu velikosti zelených řas. V učebnicích z nakladatelství Scientia (Dobroruka et al., 1999) a Fortuna (Kvasničková et al., 2002) bylo nalezeno jen po jednom nesprávném tvrzení. U učebnice z nakladatelství Scientia je mnohobuněčná jařmatka zařazena mezi jednobuněčné řasy, v učebnici od Fortuny je vláknitá větvená řasa vyobrazena mezi planktonem. Učebnice z nakladatelství Nová škola (Musilová \& Konětopský, 2007) obsahuje chybu ve výskytu pláštěnky. Žádná nesprávná tvrzení nebyla nalezena v učebnici z nakladatelství Fraus (Čabradová et al., 2003) a ve druhé učebnici z nakladatelství Nová škola (Hedbávná, 2008).

\section{C NEÚPLNÝ VÝČET}

Nedostatky v učebnicích označované jako neúplný výčet byly zjištěny v deseti případech $(16,4$ \%). V učebnici z nakladatelství Fraus (Čabradová et al., 2003) se týkají neúplných sdělení o výskytu pláštěnky, chlorofylu v jejích buňkách a rozmnožování řas. Učebnice nakladatelství Prodos (Jurčák \& Froněk, 2004) neuvádí výčet všech možností výskytu zelenivky a výskytu planktonních organismů ve stojatých vodách. 
V dalších čtyřech učebnicích se neúplný výčet týká výskytu řas. V učebnici z nakladatelství Scientia (Dobroruka et al., 1999) jde o výskyt řas na sněhu a ledu, u učebnice z nakladatelství Nová škola (Hedbávná, 2008) se chyba týká výskytu řas v planktonu, u učebnice z Nakladatelství ČGS (Maleninský et al., 2004) jde o výskyt zelenivky v akváriu, u další učebnice z nakladatelství Nová škola (Musilová \& Konětopský, 2007) jde také o výskyt řas v planktonu a učebnice od nakladatelství Fortuna (Kvasničková et al., 2002) se týká výskytu řas ve vodě.

\section{D NepřEsnost}

Kategorie 2D zahrnující nepřesnosti byla druhou nejpočetnější podkategorií odborných nedostatků. Celkem bylo ve všech učebnicích zjištěno 14 nepřesností týkající se učiva o řasách (22,9\% ze všech odborných nedostatků). Nejvíce nepřesností bylo identifikováno v učebnici nakladatelství Fraus (Čabradová et al., 2003), a to čtyři. Jde o nepřesnosti ve výskytu zelených řas ve sladké vodě a ve vyobrazení váleče a dvakrát ve vyobrazení šroubatky. V učebnicích nakladatelství Scientia (Dobroruka et al., 1999) a Prodos (Jurčák \& Froněk, 2004) bylo nalezeno po třech nepřesnostech. V první zmiňované učebnici (Dobroruka et al., 1999) byly zjištěny nepřesnosti v textu o podílu řas na vzniku atmosféry Země, v návodu na mikroskopování rozsivek a ve výběru zástupců řas označených jako nejznámější jednobuněčné zelené řasy. Ve druhé učebnici (Jurčák \& Froněk, 2004) jsou nepřesnosti ve vyobrazení řas (auxospóra rozsivky místo vegetativní stélky, špatně znázorněná dceřiná cenobia váleče) a obrázku průřezu kolonií sinice. Výskytu šroubatky v lese se týká nepřesnost zjištěná v učebnici od Fortuny (Kvasničková et al., 2002). Dvě nepřesnosti byly také nalezeny v učebnici Nové školy (Musilová \& Konětopský, 2007), obě spočívají v nepřesných návodech na mikroskopická pozorování řas (zrněnky a vodních řas). V učebnici Nakladatelství ČGS (Maleninský et al., 2004) byla nalezena pouze jedna nepřesnost, a to ve vyobrazení zrněnky.

\section{E Ostatní nedostatky}

Podkategorie $2 \mathrm{E}$ představuje nedostatky, které nebylo možno zařadit do žádné z předchozích skupin chyb. Týkají se nevýstižné formulace o kolonii váleče u učebnice z nakladatelství SPN (Černík et al., 2007), nepřesného popisu typů stélek řas u učebnice z nakladatelství Scientia (Dobroruka et al., 1999) a nevhodného přirovnání zrněnky a krásnoočka u učebnice z nakladatelství Prodos (Jurčák \& Froněk, 2004).

\section{Diskuse}

Učebnice patří k základním vzdělávacím dokumentům a měly by, kromě didaktických požadavků, také splňovat odborné požadavky příslušného vědního oboru. Vinter (2011b) uvádí, že pro více než 90 \% českých učitelů jsou během plánování výuky učebnice hlavním informačním zdrojem. Podle Kaufnerové a Vágnerové (2013) většinu informací o řasách čerpají žáci z učebnic. Náš výzkum byl zaměřen na revizi odborné správnosti učiva o řasách prezentovaného v učebnicích přírodopisu pro základní školy od sedmi různých nakladatelství. 


\subsection{ZAČLENĚNÍ ŘAS DO SYSTÉMU ORGANISMŮ}

Žádná z analyzovaných učebnic nezařazuje řasy podle nového systematického tř́idění organismů do správných systematických kategorií. Všechny řasy jsou v analyzovaném souboru učebnic, jistě v rámci zjednodušení, řazeny mezi rostliny, což ale nyní používanému systému organismů neodpovídá. Ke stejným zjištěním dospěly též Kaufnerová a Vágnerová (2013), jejichž výzkum se soustředil na analýzu učiva o sinicích a řasách v sedmi učebnicích pro ZŠ (z toho čtyři učebnice byly totožné s naším výzkumem - učebnice z nakladatelství Prodos (Jurčák \& Froněk, 2004), Fraus (Čabradová et al., 2003), Nakladatelství ČGS (Maleninský et al., 2004), SPN (Černík et al., 2007) a třech učebnicích pro střední školy. Tyto autorky uvádějí, že v případě sinic a řas nejsou v učebnicích reflektovány aktuální poznatky týkající se fylogeneze organismů, a domnívají se, že „zejména v nově vznikajících učebních textech by měly být zachyceny změny na úrovni ř́šší eukaryotických organismů" (Kaufnerová \& Vágnerová, 2013: s. 11). Problémy se zařazením řas do systému organismů zjistili $\mathrm{v}$ učebnicích určených pro přípravu k vysokoškolskému studiu biologie ve Velké Británii Donaldson a Whitton (2004). Většina jimi analyzovaných učebnic řadila řasy k rostlinám anebo je jako rostliny charakterizovala.

Vysokoškolská učebnice Kaliny a Váni (2005), na kterou naše studie odkazuje, vychází z uspořádání organismů do pěti ř́iší - Protozoa, Chromista, Plantae, Fungi a Animalia, které publikoval v druhé polovině minulého století Cavalier-Smith (1981, 1986). Aktuálně uznávaný systém organismů uvádějí Keeling et al. (2009) a moderní pohled na organizaci organismů publikovali v roce 2012 také Adl et al. Řasy jsou podle těchto publikací většinou zařazeny do čtyř skupin (Macháček et al. (2016) je označují jako superskupiny), z nichž některé jsou na úrovni říší.

Tento nejnovější pohled na systém organismů nebyl v českém jazyce v učebnicích pro ZS̆ nebo SS̆ publikován. V ČR rovněž zatím nebyla vydána žádná vysokoškolská učebnice zařazující řasy do aktuálního systému. Podle nám dostupných informací jsou řasy podle moderního systému přednášeny na Přrirodovědeckých fakultách MU, UK, JČU. Z Pedagogických fakult je výuka podle nového systému realizována na ZČU. Také některé střední školy už podle nového systému zřejmě učí. Informace máme například z Gymnázia Břeclav (P. Král - ústní sdělení). V češtině představují zařazení řas do moderního systému ve svých článcích Kaufnerová a Vágnerová (2013) a Kaštovský a Juráň (2016). Publikace Kaštovského a Juráně (2016) se podrobně věnuje fylogenetickým vztahům mezi skupinami řas, článek Juráně a Kaštovského (2016) na ni navazuje návrhy výuky řas na středních školách podle moderního systému. Kaufnerová a Vágnerová (2013) kromě postavení řas v aktuálním systému organismů (v př́loze jejich práce) navrhují skupiny sinic a řas a jejich zástupce vhodné pro výuku na ZS a SS̆ i s jejich moderním zařazením do systému organismů. Implementací nového systému u dalších skupin organismů se zabývali také Dvořáková a Absolonová (2017), Macháček et al. (2016), Musilová (2016), Šebková (2016), Štech (2016) a Vilímová (2016).

Analyzované učebnice byly publikovány v letech 1999 až 2008. Rozpětí téměř 10 let jistě mělo také vliv na informace o systematickém zařazení řas uváděné v učebnicích, protože vědecký výzkum v této oblasti velmi pokročil. Není samozřejmě možné, aby se změny v systematickém řazení organismů hned odrazily v učebnicích pro základní školy.

Systematické uspořádání však odráží vývojové vztahy mezi organismy. Jistě je možné systematiku řas neučit vůbec a zvolit pouze ekologický přístup, ovšem základní fylogenetické vztahy mezi řasami a jejich postavení vůči jiným organismům 
je třeba znát a ve výuce s nimi pracovat. Zajímavou diskusi o významu výuky taxonomického tř́́dění organismů (určenou spíše pro středoškolské učitele) jsme nalezly v článku Američanky Caseové (2008). Autorka navrhuje představit si při výuce biologie studenty, kteří prezentují nikoliv své znalosti systému organismů, ale diskutují o významu klasifikačního systému, uvědomují si způsob klasifikování i vznikající nesrovnalosti. Podle této autorky si tím studenti lépe osvojí základní hypotézy o původu a vývoji organismů. Domníváme se, že základy vývoje organismů na Zemi tedy i k sekundárnímu vzdělávání patří. Cílem by nemělo být to, aby žáci znali správné zařazení organismů do systematických jednotek, ale spíše, aby pochopili základy vývoje organismů a důsledky z něj plynoucí.

Řasy jsou polyfyletickou skupinou, což znamená, že tyto organismy nikdy neměly společného předka (Juráň \& Kaštovský, 2016) a systematicky tedy nemohou být řazeny do jedné skupiny. I přes rozdílný původ však plní všechny řasy v ekosystémech úlohu producentů, mnohé navíc mají stejnou ekologii a výskyt. Ekologický přístup k pojetí učiva u učebnice z nakladatelství Fortuna (Kvasničková et al., 2002) se jeví z tohoto pohledu jako ideální.

\subsection{DALŠí ODBORNÉ CHYBY A NEDOSTATKY}

Celkem bylo v osmi analyzovaných učebnicích v učivu o řasách nalezeno 61 odborných nedostatků. Přitom pouze jeden typ chyby se vyskytoval ve všech osmi analyzovaných učebnicích - stélka váleče je správně cenobium, neodpovídá označení pouhé kolonie a byl tedy osmkrát započítán. Také Kaufnerová a Vágnerová (2013: s. 9) nalezly v učivu o řasách v učebnicích pro ZŠS „neaktuální, neúplné či zavádějící informace". Identifikovaly chyby v systematickém zařazení řas, absenci informací o významu řas $\mathrm{v}$ př́rodě a jejich využití člověkem. Na rozdíl od našeho výzkumu se také zabývaly výběrem zástupců řas prezentovaných $\mathrm{v}$ učebnicích přírodopisu. Obě autorky chyby nekvantifikovaly a nepoužily žádnou kategorizaci chyb, rovněž nepoužily $\mathrm{k}$ analýzám stejnou metodu, jaká je použita v našem výzkumu. Nicméně některá jejich zjištění jsou v souladu s výsledky našeho výzkumu (viz výše u zařazení řas do systému a dále $\mathrm{v}$ textu).

Nesprávná tvrzení patřila $\mathrm{v}$ analyzovaných učebnicích $\mathrm{k}$ nejhojnějším nedostatkům. Tyto nedostatky mají různou míru závažnosti a mnohé jsou v rámci didaktického zpracování vědeckých poznatků pochopitelné. Přesto se domníváme, že některé z nich by se neměly v učebnicích vyskytovat. Zatímco některé př́ípady, např. použití termínu kolonie místo cenobium u váleče, je možno v rámci zjednodušení používat, faktická chyba, použití mikrofotografie ruduchy Audouinella v učebnici z nakladatelství SPN (Černík et al., 2007) místo zelené řasy žabí vlas (Cladophora), by se stát neměla. Takové chyby přece nejsou zatíženy velkou náročností didaktické transformace vědeckých poznatků. Chybné tvrzení o dutinkách (vakuolách) v sinicích naplněných dusíkem uvedené v učebnici z nakladatelství Prodos (Jurčák \& Froněk, 2004) bylo zjištěno nejenom našim výzkumem, ale také Kaufnerovou a Vágnerovou (2013). Nad chybnými odbornými výrazy použitými v učebnicích a učebních textech z biologie vyšších rostlin se zamýšlel Vinter (2011a, 2011b), s poukázáním, že výsledky ve vzdělávání závisí mj. také na kvalitní studijní literatuře. Některá chybná odborná tvrzení by mohla mít dopad na takové vědomosti žáků, které tvoří základ pochopení vztahů mezi organismy a na kterých budou během svého vzdělávání stavět. Př́́kladem jsou chybně uvedené organismy v potravní pyramidě nebo informace, že rozsivky většinou nejsou potravou jiných organismů, které se vyskytují v učebnici z nakladatelství Prodos (Jurčák \& Froněk, 2004). 
Dostál (1998) uvádí, mimo jiné, př́klady nepřesností a odborných chyb, které charakterizoval jako kategorická tvrzení s jednoznačným zobecněním a která se mohou negativně promítnout do formování vědomostí žáků. Také v učebnicích ZS̆ v učivu o řasách jsme během našeho výzkumu objevily několik takovýchto nedostatků. Typickým prŕkladem jsou informace o výskytu řas v př́rodě, které jsou často neúplné, nedostatečné.

Domníváme se, že tvrzení o řasách nepřipouštějící další možnosti může způsobit nedostatečné žákovo chápání rolí řas v př́rodě.

Naše výsledky také ukazují nevhodná zjednodušení odborných poznatků v učivu o řasách. Například tvrzení, že řasám vděčíme za atmosféru Země uvedené v učebnici z nakladatelství Scientia (Dobroruka et al., 1999), by mohlo u žáků vést ke zkresleným představám o vývoji života na Zemi.

Rada obdobných nedostatků byla také zjištěna při analýze učiva o řasách v britských učebnicích biologie. Donaldson a Whitton (2004) ve svém článku uvádějí např́klad chybná tvrzení (např. o stavbě stélky řas), zavádějící tvrzení, př́lišné generalizace (všechny řasy jsou malé) nebo opomenutí významu řas v ekosystému (role řas v oceánu). Podobně jako my, také tito autoři zjistili v učebnicích použití nesprávného odborného termínu v souvislosti s řasami (,some algae feed on organic material“). Tito autoři se rovněž zamýšlejí nad kontextem problematiky řas a biologických principů a pochopení biologických dějů.

Pro zpracování učiva o řasách autorky doporučují zvolit kombinaci systematického a ekologického přistupu s důrazem na ekologii řas a jejich význam pro člověka.

Do výuky na ZŠ navrhujeme začlenit tyto skupiny řas: hnědé, červené, zelené a ostatní (zahrnující krásnoočka a obrněnky), čímž budou pokryty hlavní skupiny řas s běžnými zástupci (krásnoočka a obrněnky byly vybrány také s ohledem na některé zástupce, kteří nemají chlorofyl a živí se heterotrofně). Nástin vývoje organismů by mohl být začleněn do výuky ještě před výukou o řasách. Pro efektivnost výuky by bylo vhodné nejprve identifikovat představy a poznatky žáků o řasách a nové pojmy stavět na těch již osvojených. V tomto směru je klíčové rozpracování návaznosti učiva 1. a 2. stupně ZS̆, které v České republice zcela chybí a mělo by být jedním z úkolů výzkumu v oblasti oborových didaktik.

Pro motivaci žáků lze zvolit názornou ukázku zástupců hlavních skupin řas (ideálně makroskopických, s různými typy stélky), čímž bude zároveň demonstrována pestrost řas. Zelené řasy lze žákům demonstrovat na chomáči žabího vlasu (případně jiné makroskopické zelené řasy, podle toho, kde se škola nachází). Žabí vlas je řasa vláknitá, makroskopická. Jako ukázka červených řas se hodí jakákoliv ruducha z moře (ideálně z toho, ke kterému se běžně jezdí na dovolenou, protože osobní zkušenost žáků s řasami lze využít jako motivaci (Nolčová \& Vágnerová, 2016)), která má červenou barvu (sladkovodní ruduchy jsou také makroskopické, ale u nás běžné druhy nemají červenou barvu). Pro demonstraci hnědých řas by byla vhodná jakákoliv makroskopická chaluha, např. Padina pavonica, která je hojná na pobřeží Jaderského moře v Chorvatsku a kámen s hnědým rozsivkovým povlakem vytažený ze sladkých vod. Zástupce ostatních řas - krásnoočka - lze demonstrovat na zelené vodě z rybníka. Téměř každý rybník v ČR je eutrofizovaný a žijí v něm krásnoočka, která jsou sice mikroskopická, ale při přemnožení běžných druhů má voda v rybníce zelenou barvu. Pro přehlednost a první (nebo jedno z prvních) seznámení žáků s fylogenetickým vývojem organismů je třeba roztřídit řasy do skupin - zelené, červené, hnědé a ostatní a uvést jejich začlenění do hlavních moderních systematických jednotek s vysvětlením, proč jsou tak uspořádány. Je vhodné začít skupinami, které 
řadíme k rostlinám, což jsou zelené řasy a červené řasy. Více př́íkladů/zástupců už bychom v této fázi neuváděly.

Další třídění řas by již bylo podle jejich ekologie se zaměřením na hlavní biotopy, ve kterých se řasy vyskytují a úlohu, kterou v ekosystému hrají. Za hlavní biotopy výskytu řas považujeme sladkovodní stojaté a tekoucí vody, moře, kůru stromů/zdi domů/skály a půdu. V př́padě stojaté a tekoucí vody je dobré uplatnit regionální princip - uvádět řasy ve vodním biotopu, který je všem žákům znám. Domníváme se, že ekologické pojetí výuky řas je z hlediska své komplexnosti pro žákovy vědomosti přínosnější než pojetí systematické a zároveň je velkým vkladem do dalších hodin biologie.

Výuka by měla být doplněna pozorováním řas pomocí mikroskopu - pro méně kvalitní mikroskopy lze zvolit žabí vlas, u kvalitnějších pak rozsivky z kamene ukazovaného na začátku výuky.

\section{ZÁVĚR}

Obsahová analýza textu učiva o řasách osmi učebnic př́rodopisu pro druhý stupeň základních škol a nižší stupeň víceletých gymnázií zaměřená na odborné nedostatky v textu přinesla překvapivé výsledky. Celkem byly zjištěny čtyři kategorie nedostatků v zařazení řas do systému organismů a 61 dalších odborných nedostatků v učivu. Nejhojnější odbornou chybou týkající se systematického zařazení řas bylo řazení všech řas k rostlinám. To odporuje staršímu i modernímu systematickému pojetí tř́idění organismů a mohlo by podle autorek vést u žáků $\mathrm{k}$ nesprávnému pochopení vývoje organismů na Zemi. Z odborného hlediska převažovaly nedostatky týkající se odborných tvrzení, kdy celá tvrzení byla chybná. Chyby byly zjištěny také v odborných termínech a zahrnovaly nepřesnosti $\mathrm{v}$ textu a neúplné výčty možností v jinak správných informacích o řasách.

Důvodů, které vedou k odborným nedostatkům v učivu o řasách v učebnicích pro základní školu, bude jistě více a lze jen těžko všechny určit. Některé nedostatky jsou přejímány ze starších vydání učebnic. Důvodem přebírání již překonaných faktů ze starších učebnic může být také komplikované zařazení řas do systému organismů. Algologie jako multidisciplinární obor je nejen vědecky náročná, ale je také poznamenána neustálým pokrokem v poznatcích, a to nejen ve fylogenetickém postavení řas. Vědecký pokrok nemůže být zachycen v učebnicích staršího vydání a odraz nových vědeckých poznatků v nově vydávaných učebnicích bude mít pochopitelně zpoždění. Abimbola a Baba (2013) publikovali článek, který v této souvislosti ukazuje učitelům, jak v učebnicích chyby vyhledávat (článek se týká miskoncepcí v učebnicích biologie), uvádí zdroje, kde mohou analýzu učebnic sledovat a nabádá je, aby konzultovali nejasnosti v učebnicích s odborníky.

Z procesu didaktické transformace je uváděn jako důvod odborných nedostatků zjednodušování učiva (Dostál, 1998; Kaufnerová \& Vágnerová, 2013), což můžeme našimi výsledky potvrdit. Snaha o zjednodušení a zpř́stupnění problémů chápání žáků však může vést podle Dostála (1998) k vulgarizaci vědy a chybným představám žáků. Stejný autor uvádí, že nepřesnosti a chyby ve vysvětlování dějů (kromě snah o př́lišné zjednodušení má na mysli také kategorická tvrzení s jednoznačným zobecněním) mohou být př́činou zkreslených představ žáků a nepřesností v jejich vědomostech. Vinter (2011a) upozorňuje, že kvalitní učebnice by měly být odborně správné a korektní, s informacemi odpovídajícími poznatkům vědy. S odbornou správností informací v učebnicích se pak pojí ovlivnění znalostí žáků a utváření je- 
jich konceptů a postojů k biologickým poznatkům. Ovšem proces didaktické transformace vědeckých poznatků do podoby využitelné na ZŠ je náročný a vyžaduje kompromisy.

Zástupci řas jsou v analyzovaných učebnicích ZŠ uvedeni bez zamyšlení se nad tím, jak hojní v přírodě jsou, jaký význam v přírodě mají, jak je může člověk využít a jak jsou pro učitele dostupné (Kaufnerová \& Vágnerová, 2013). Přitom podle našeho názoru, cílem učiva o řasách není jen žáky seznámit s těmito organismy a jejich významem v př́rodě, ale také žáky naučit, jaký mají řasy pro člověka praktický význam. Informace podané s přihlédnutím k tomuto aspektu si žáci nejlépe zapamatují.

V diskusi jsme navrhly koncepci výuky řas, o které se domníváme, že by po rozpracování a ověření v praxi mohla přispět ke kvalitnějším poznatkům žáků. Preferujeme ekologické pojetí učiva, nicméně vzhledem k nástinu fylogenetických vztahů mezi organismy doporučujeme ponechat aspoň základní systematické třídění řas podle moderního systému. Myslíme si, že vůbec prvním výzkumem, který by mohl vést ke kvalitnímu učebnímu textu, by měl být výzkum v oblasti návaznosti učiva a identifikace představ žáků o řasách. Prvním počinem v tomto směru je diplomová práce spoluautorky článku Hvězdové (2018) představující výzkum představ žáků o řasách $\mathrm{v}$ rámci modelu didaktické rekonstrukce. Výsledky prezentované $\mathrm{v}$ tomto článku by mohly sloužit učitelům jako upozornění na odborné nedostatky $\mathrm{v}$ učivu o řasách v učebnicích, které používají, a jsou prvním krokem k celkovému odbornému a didaktickému rozboru učiva o řasách.

\section{LITERATURA}

Adl, S. M., Simpson, A. G. B., Lane, C.E., Lukeš, J., Bass, D., Bowser, S. S., Brown, M. W., Burki, F., Dunthorn, M., Hampl, V., Heiss, A., Hoppenrath, M., Lara, E., Le Gall, L., Lynn, D. H., Mcmanus, H., Mitchell, E. A. D., Mozley-Stanridge, S.E., Parfrey, L. W., Pawlowski, J., Rueckert, S., Shadwick, L., Schoch, C. L., Smirnov, A. \& Spiegel, F. W. (2012). The revised classification of eukaryotes. Journal of Eukaryotic Microbiology, 59(5), 429-104.

Aimbola, O. \& Baba, S. (1996). Misconceptions \& alternative conceptions in science textbooks: The role teachers as filters. The American Biology teacher, 8, 14-19.

Ambrožová, J. (1999). Acidifikace šumavských jezer - Cerného a Certova. Vodní hospodářství, 49(6), 117-119.

Baldauf, S. L., Roger, A. J., Wenk-Siefert, I. \& Doolittle, W. F. (2000). A kingdom-level phylogeny of eukaryotes based on combined protein data. Science, 90(5493), 972-977.

Case, E. (2008). Teaching taxonomy: How many kingdoms? The American Biology Teacher, 70(8), 472-477.

Cavalier-Smith, T. (1981). Eukaryote kingdoms: Seven or nine? BioSystems, 14(3-4), 461-481.

Cavalier-Smith, T. (1986). The kingdom Chromista: origin and systematics. In F. E. Round \& D. J. Chapman (Eds.), Progress in Phycological Research (309-347). Bristol: Biopress.

Cavalier-Smith, T. (1998). A revised six-kingdoms system of life. Biological Reviews, 73(3), 203-266. 
Cyrus, Z. \& Hindák, F. (1978). Euglenophyceae - červenoočká (euglény). In F. Hindák (Ed.), Sladkovodné riasy (651-692). Bratislava: SPN.

Cabradová, V., Hasch, F., Sejpka, J. \& Vaněčková, I. (2003). Přírodopis pro 6. ročník základni školy a primu víceletého gymnázia. Plzeň: Fraus.

Černík, V., Hamerská, M., Martinec, Z. \& Vaněk, J. (2007). Přírodopis 6 pro základní školy: Zoologie a botanika. Praha: SPN.

Červenková, I. (2011). Užívání učebnic v činnostech žákio na 2. stupni ZS̆ [Disertační práce]. Olomouc: UP.

Dobroruka, L. J., Cílek, V., Hasch, F. \& Storchová, Z. (1999). Přírodopis I pro 6. ročník $Z \check{S}$. Praha: Scientia.

Donaldson, A. M. \& Whitton, B. A. (2004). Teaching Alage, „Algae are not plants anymore!“. In A. R. Taylor (Eds.), The Phycologist. The Newsletter of the British Phycological Society, 66, 10-11.

Dostál, P. (1998). K některým omylům a rozporům ve výkladu biologických poznatků. Biologie, chemie, zeměpis, 7(3), 97-99.

Dvořáková, R. M. \& Absolonová, K. (2017). Vznik a vývoj člověka. Živa, 65(1), 26-28.

Ettl, H. (1983). Chlorophyta I, Phytomonadina. In H. Ettl, J. Gerloff, H. Heynig \& D. Mollenhauer (Eds.), Süßwasserflora von Mitteleuropa (1-807). Stuttgart, New York: Gustav Fisher Verlag.

Gavora, P. (2010). Úvod do pedagogického výzkumu. Brno: Paido.

Gavora, P. (2015). Obsahová analýza v pedagogickom výskume: Pohlad na jej súčasné podoby. Pedagogická orientace, 25(3), 345-371.

Granéli, E. \& Turner, J. T. (2002). Top-down regulation in ctenophore-copepod-ciliate-diatom-phytoflagellate communities in coastal waters: a mesocosm study. Marine ecology progress series, 239, 57-68.

Guiry, M.D. \& Guiry, G. M. (2017a). AlgaeBase, World-wide electronic publication. Dostupné z http://www.algaebase.org

Guiry, M. D. \& Guiry, G. M. (2017b). AlgaeBase, World-wide electronic publication. Cladophora Kützing, 1843, nom. cons. Dostupné z http://www.algaebase.org/search/genus/detail/?genus_id=v1e7ff6da161a9cd4\&sk=0

Hedbávná, H. (2008). Přírodopis 2. díl: Botanika. Brno: Nová škola.

Hendl, J. (2005). Kvalitativní výzkum. Praha: Portál.

Hindák, F. (Ed.). (1978). Sladkovodné riasy. Bratislava: SPN.

Hvězdová, K. (2018). Představy žáků o řasách: výzkum v rámci modelu didaktické rekonstrukce [Diplomová práce]. Brno: MU.

Dostupné z https://is.muni.cz/th/371241/pedf_m/Diplomova_prace.pdf?info=1; zpet $=\% 2$ Fvyhledavani $\% 2 \mathrm{~F} \% 3$ Fsearch $\% 3 \mathrm{DP} \% \mathrm{C} 5 \% 99$ edstavy $\% 20 \% \mathrm{C} 5 \% \mathrm{BE} \% \mathrm{C} 3 \% \mathrm{~A} 1 \mathrm{k}$ \%C5\%AF\%20o\%20\%C5\%99as\%C3\%A1ch\%20agenda:th\%26start\%3D1

Juráň, J. \& Kaštovský, J. (2016). Nový pohled na systém řas a jak ho učit? Živa, 4(6), 299-301.

Jurčák, J. \& Froněk, J. (2004). Přírodopis 6. Olomouc: Prodos.

Kalina, T. \& Váňa, J. (2005). Sinice, řasy, houby, mechorosty a podobné organismy v současné biologii. Praha: Karolinum. 
Kaštovský, J. \& Hauer, T. (2017a). Sinice a řasy.cz.

Dostupné z http://www.sinicearasy.cz/

Kaštovský, J. \& Hauer, T. (2017b). Sinice a řasy.cz, Oddělení Cyanobacteria.

Dostupné z http://www.sinicearasy.cz/134/Cyanobacteria

Kaštovský, J. \& Hauer, T. (2017c). Sinice a řasy.cz, Tř́da Bacillariophyceae.

Dostupné z http://www.sinicearasy.cz/134/Bacillariophyceae

Kaštovský, J. \& Hauer, T. (2017d). Sinice a řasy.cz, Tř́́da Trebouxiophyceae.

Dostupné z http://www.sinicearasy.cz/134/Trebouxiophyceae

Kaštovský, J. \& Hauer, T. (2017e). Sinice a řasy.cz, Tř́da Ulvophyceae.

Dostupné z http://www.sinicearasy.cz/134/Ulvophyceae

Kaštovský, J. \& Juráň, J. (2016). Evoluce sinic a řas v moderním pojetí. Živa, 64(6), CXXXIII-CXXXVI.

Kaufnerová, V. \& Vágnerová, P. (2013). Sinice a řasy v učebnicích pro základní a střední školy. Arnica, (3)1-2, 9-18.

Keeling, P., Leander, B. S. \& Simpson, A. (2009). Eukaryota: Organisms with nucleated cells. Dostupné z http://tolweb.org/Eukaryotes/3

Knecht, P. (2007). Didaktická transformace anebo od „Didaktického zjednodušení“ k „Didaktické rekonstrukci“. Orbis scholae, 1(1), 67-81.

Knox, G. A. (2000). The Ecology of Seashores. New Brunswick: CRC Press.

Kvasničková, D., Jeník, J., Pecina, P., Froněk, J. \& Cais, J. (2002). Ekologický př́rodopis pro 6. ročník základni školy a nižši ročníky víceletých gymnázii. Praha: Fortuna.

Lukavský, J. (2014). Barevný sníh. Botanika, 2(1), 3-4.

Dostupné z http://www.ibot.cas.cz/botanika/casopis_BOTANIKA_2014_1_Barevnysnih.html

Macháček, T., Mikešová, K., Turjanicová, L. \& Hampl, V. (2016). Proměny vyšší systematiky eukaryot a její odraz ve středoškolské biologii. Živa, 64(1), 27-30.

Maleninský, M., Smrž, J. \& Škoda, B. (2004). Př́rodopis pro 6. ročník, Botanika 1, Zoologie 1. Praha: Nakladatelství České geografické společnosti.

Mikk, J. (2007). Učebnice: budoucnost národa. In J. Maňák \& P. Knecht (Eds.), Hodnocení učebnic (11-22). Brno: Paido.

Musilová, Z. (2016). Skrytá rozmanitost pod vodní hladinou: evoluce druhově nejbohatší skupiny obratlovců. Živa, 64(4), 175-178.

Musilová, E. \& Konětopský, A. (2007). Př́rodopis 1. díl: Úvod do učiva přírodopisu. Brno: Nová škola.

Nedbalová, L. \& Lukavský, J. (2007). Když sníh zčervená, aneb co (ne)víme o sněžných řasách. Živa, 55(3), 104-107.

Nogová, M. (2008). Hodnotenie kvality učebníc v súlade s novým kurikulom. In

P. Knecht \& T. Janík (Eds.), Učebnice z pohledu pedagogického výzkumu (37-51). Brno:

Paido.

Nolčová, L. \& Vágnerová, P. (2016). Zajímavá a motivující výuka řas a sinic na základních a středních školách. Arnica, 5(1-2), 32-38.

Průcha, J. (1998). Učebnice: Teorie a analýzy edukačního média. Brno: Paido. 
Průcha, J. (2009). Moderní pedagogika. Praha: Portál.

Rámcový vzdělávací program pro základní vzdělávání. (2016). Praha: VÚP.

Dostupné z http://www.nuv.cz/uploads/RVP_ZV_2016.pdf

Rosypal, S. (Ed.). (1992). Fylogeneze, systém a biologie organismů. Praha: SPN.

Simpson, A. G. B. \& Roger, A. J. (2004). The real „kingdoms“ of Eukaryotes. Current Biology, 14(8), 693-696.

Skalková, J. (2006). K některým aktuálním problémům všeobecného vzdělání v kontextu učící se a globalizující se společnosti. Pedagogická orientace 16(1), 2-17.

Skalková, J. (2007). Obecná didaktika. Praha: Grada.

Šebková, K. (2016). Implementace nového systému krytosemenných rostlin do vzdělávání žáků středních škol. Biologie-Chemie-Zeměpis, 25(4), 177-187.

Šmarda, J. (2009). O sinicích. Universitas, 42(1), 3-10.

Sttech, M. (2016). Jak přenést příběh cévnatých rostlin do středoškolské biologie. Živa, 64(2), 70-75.

Vilímová, J. (2016). Zajímavé změny v chápání fylogeneze a systému živočichů. Živa, $64(3), 125-128$.

Vinter, V. (2011a). K některým nepřesnostem a omylům v učivu biologie rostlin na gymnáziích a středních školách (1). Biologie-Chemie-Zeměpis, 20(2), 61-63.

Vinter, V. (2011b). K některým nepřesnostem a omylům v učivu biologie rostlin na gymnáziích a středních školách (2). Biologie-Chemie-Zeměpis, 20(3), 117-120.

Víden, I. (2005). Chemie ovzduší. Praha: Vysoká škola chemicko-technologická v Praze.

Vrtiška, O. (2014). Miliarda let nudy před velkým nadechnutím.

Dostupné z http://vesmir.cz/2014/11/15/miliarda-let-nudy-pred-velkym-nadechnutim/

\section{Přílloha: KonkRÉTNÍ NEDOSTATKY V UČIVU \\ O ŘASÁCH V ANALYZOVANÝCH UČEBNICÍCH A JEJICH NÁPRAVA}

\section{UČEBNICE Př́RODOPISU Z NAKLADATELSTVÍ Fraus (ČABRadová ET AL., 2003)}

Čabradová, V., Hasch, F., Sejpka, J. \& Vaněčková, I. (2003). Přírodopis pro 6. ročník základni školy a primu víceletého gymnázia. Plzeň: Fraus.

\section{NEDOSTATKY SPOJENÉ SE SYSTEMATICKÝM ZǍ̌AZENÍM ŘAS}

\section{A SYSTÉM/ROSTLINY}

- Úvodní název kapitoly o řasách „řasy - stélkaté rostliny“ (s. 42) neodpovídá vědeckým poznatkům, řasy jsou řazeny podle Kaliny a Váni (2005) nejen do ř́še Rostliny (Plantae), ale také do ř́ı́ší Prvoci (Protozoa) a Chromista. Podle moderního systému Adla et al. (2012) jsou do skupiny Archaeplastida, kam patří také rostliny, z řas řazeny pouze řasy červené (ruduchy) a řasy zelené. Není tedy možné všechny řasy nazývat rostlinami. 


\section{B ZÁMĚNA ODDĚLENÍ}

- Krásnoočko zelené a šroubatka jsou řazeny v učebnici (s. 42, 43) mezi zelené řasy, což neodpovídá vědeckým poznatkům. Krásnoočko je podle Kaliny a Váni (2005) řazeno správně mezi prvoky (ř́ı̌se Protozoa), šroubatka do oddělení Parožnatky (Charophyta), nikoli do oddělení Zelené řasy (Chlorophyta). Z učebnice nevyplývá, že by skupina zelené řasy byla myšlena jako skupina řas se zelenou barvou. Podle Adla et al. (2012) je krásnoočko řazeno do skupiny Excavata spolu s jinými prvoky.

\section{$1 \mathrm{C}$ NIŽŠí ROSTLINY}

- Informace v postranní liště na s. 42 „řasy řadíme mezi nižší rostliny“ není odborně správně. Skupina Nižší rostliny byla dřive na úrovni podříše řazena do říše Rostliny a zahrnovala kromě řas také houby a lišejníky (např. Rosypal et al., 1992). Toto systematické tř́ídění organismů se ale již dlouhou dobu nepoužívá (viz Cavalier-Smith, 1981).

\section{DALŠÍ ODBORNÉ NEDOSTATKY}

\section{A NESPRÁVNÝ ODBORNÝ TERMÍN}

- U váleče je uvedeno, že se jedná o kolonii (s. 42), váleč ale tvoří tzv. cenobium (Kalina \& Váňa, 2005: s. 461), což je, jak zmínění autoři vysvětlují „několikabuněčný celek $\left(2^{n}\right) \mathrm{s}$ určitým, často geometricky pravidelným uspořádáním buněk jedné generace“. Zatímco kolonie jsou skupiny buněk nebo i skupiny vláken obalených slizem a počet buněk v kolonii není $2^{n}$ (Kalina \& Váňa, 2005). V terminologickém slovníku pak Kalina a Váňa (2005: s. 548) označují cenobium jako „zvláštní druh kolonie, tvořené jedinou generací buněk, které bývají specifickým způsobem spojené a pravidelně uspořádané; rozmnožují se dceřinými cenobii".

- Na s. 43 je uvedena informace, že šroubatka a žabí vlas vytvářejí vláknité kolonie, což je pro představu o uspořádání těchto řas zavádějící, pro uspořádání vláken se v př́ípadě chomáčů vláknitých řas výraz kolonie nepoužívá, odborníci opravdu označují skupiny těchto vláken jako chomáče.

\section{C NEÚPLNÝ VÝČET}

- Informace, že pláštěnka žije ve stojatých vodách bohatých na živiny, není zcela přesná, mnoho druhů pláštěnek žije i ve vodách na živiny chudých (např. Ambrožová, 1999) nebo jinde než ve stojaté vodě, např. na sněhu (Nedbalová \& Lukavský, 2007) nebo v rašelinných vodách (Hindák, 1978).

- Na s. 42 je uvedena informace „krásnoočko zelené a pláštěnka jsou příkladem jednobuněčných zelených řas. Jejich buňky obsahují chloroplasty se zelení listovou - chlorofylem, který jim umožňuje výživu“. Dochází zde k př́lišné konkretizaci - v kontextu celé kapitoly není jasné, zda autoři připisují chloroplasty s chlorofylem pouze krásnoočku zelenému a pláštěnce nebo všem jednobuněčným zeleným řasám. Motivační text ani úvodní dva řádky kapitoly nenavádí k pochopení, že se toto tvrzení týká všech řas.

U dalších zelených řas (zelenivka, zrněnka, váleč, šroubatka, žabí vlas), zmiňovaných v kapitole, se už také o chloroplastech a zeleni listové nehovoří. 
- Na s. 43 je výrok „zrněnka, zelenivka i krásnoočko se rozmnožují dělením“ př́liš konkrétní. Tvrzení dělá dojem, jako by se žádné jiné řasy dělením nerozmnožovaly.

\section{D NEPŘESNOST}

- Schéma (či obrázek) váleče na s. 42 neodpovídá skutečnosti, obrázek budí dojem, že buňky jsou opatřeny jedním bičíkem, který se rozdvojuje, což ale není pravda, z každé buňky jdou bičíky dva (viz např. Kalina \& Váňa, 2005; Hindák, 1978).

- Informace „zelené řasy žijí hlavně ve sladké vodě“ (s. 43) je těžko ověřitelná a velmi obecně formulována. To samé lze konstatovat o informaci „nejvíce řas se vykytuje v moři“. Jednak není jasné, jestli je myšlen nejvyšší počet taxonů nebo nejvyšší počet jedinců, a i v mořích žije celá řada zástupců zelených řas (např. Cladophora - různé druhy, Halimeda tuna, Acetabularia acetabulum, Ulva lactuca a další) a mnohdy masově.

- Na fotografii šroubatky pod mikroskopem (s. 43) je šroubatka v době pohlavního rozmnožování - spájení. Po většinu vegetační sezóny ale tak šroubatka nevypadá. Naopak chybí na fotografii pro šroubatku typicky uspořádaný šroubovitě vinutý chloroplast, na který odkazuje její jméno.

- U schématu šroubatky (s. 43) není vyznačeno, že se jedná o schéma, nemůže se jednat o kresbu z mikroskopu, jinde než ve speciálním mikroskopu po zvláštních úpravách by nebyly vidět jádra buněk. Pokud by vidět byly, řasa by vypadala jinak.

\section{UČEBNICE PříRODOPISU Z NAKLADATELSTVÍ SPN (ČERNÍK ET AL., 2007)}

Černík, V., Hamerská, M., Martinec, Z. \& Vaněk, J. (2007). Př́rodopis 6 pro základní školy: Zoologie a botanika. Praha: SPN.

\section{NEDOSTATKY SPOJENÉ SE SYSTEMATICKÝM ZǍ̌AZENÍM ŘAS}

\section{A SYSTÉM/ROSTLINY}

- Všechny řasy jsou v učebnici řazeny mezi rostliny, text o řasách má nadpis „Rostliny - vybrané skupiny“ a podnadpis „ட̌rasy - stélkaté rostliny“ (s. 78), jsou zde však uváděny také chaluhy, rozsivky a krásnoočko, které mezi rostliny, tedy do říše Plantae, nepatř́i. Kalina a Váňa (2005) chaluhy a rozsivky řadí do říše Chromista, krásnoočko do říše Protozoa (Prvoci). Podle moderního systému Adla et al. (2012) jsou do skupiny Archaeplastida, kam patří také rostliny, z řas řazeny pouze řasy červené (ruduchy) a řasy zelené. Kránoočka (spolu s jinými prvoky) Adl et al. (2012) řadí do skupiny Excavata. Není tedy možné všechny řasy nazývat rostlinami.

\section{DALŠÍ ODBORNÉ NEDOSTATKY}

\section{A NESPRÁVNÝ ODBORNÝ TERMÍN}

- U váleče je uvedeno, že se jedná o kolonii. Přesněji jde ale o cenobium. Komentář viz výše u podkategorie $2 \mathrm{~A}$ v textu k učebnici Čabradové et al. (2003) na s. 1-2 přílohy. 
- Na obr. 11 (s. 80) je pod mikrofotografií uvedeno, že se jedná o žabí vlas, na fotografii je ale sladkovodní ruducha Audouinella.

- Na s. 80 autoři uvádějí, že žabí vlas žije převážně ve sladkých vodách. Toto tvrzení není zcela přesné a je těžko ověřitelné. Podle databáze (Guiry \& Guiry, 2017b) se zástupci rodu žabí vlas (Cladophora) vyskytují ve sladkovodních, brakických a mořských vodách, rovněž Kaštovský a Hauer (2017e) ji označují jako mořský a sladkovodní rod.

- Na začátku kapitoly (s. 78) o řasách je uvedeno, že „vědci je dělí podle složení barviva umožňujícího fotosyntézu, podle složení buněčné stěny a zásobních látek i typu jejich těla“. Tato informace je v současnosti zastaralá, neúplná. K objasnění vztahů mezi organismy, které jsou základem jejich systematického třídění, se využívá kromě morfologie stélek, zejména sekvence SSU rDNA (Kalina \& Váňa, 2005), a také některé další znaky specifické podle skupiny řas. Metody molekulární biologie a fylogenetiky přinesly změny v chápání taxonomie a fylogeneze eukaryotních organismů (Juráň \& Kaštovský, 2016), a to už ke konci minulého století.

\section{E OSTATní}

- Tvrzení na s. 80 „váleč má tu zvláštnost, že jeho kulovité tělo je kolonií zelených řas opatřených bičíky" budí dojem, že váleč by mohl být tvořen jakoukoliv zelenou řasou opatřenou bičíkem.

\section{UČEBNICE P̌̌́́RODOPISU Z NAKLADATELSTVÍ Scientia (Dobroruka ET AL., 1999)}

Dobroruka, L. J., Cílek, V., Hasch, F. \& Storchová, Z. (1999). Přírodopis I pro 6. ročnik $Z \breve{S}$. Praha: Scientia.

\section{NEDOSTATKY SPOJENÉ SE SYSTEMATICKÝM ZAŘAZENÍM ŘAS}

\section{A SYSTÉM/ROSTLINY}

- V textu se běžně hovoří o řasách jako rostlinách, ale všechny řasy v učebnici uvedené do ř́šse Rostliny (Plantae) podle Kaliny a Váni (2005) nebo skupiny Archeplastida, která odpovídá rostlinám (podle Adla et al., 2012), nepatří. Dinobryon (znázorněn na obr. na s. 52, bez názvu taxonu), rozsivky a chaluhy se řadí do říše Chromista (podle Kaliny \& Váni, 2005), podle Adla et al. (2012) do Stramenopila skupiny SAR. Ceratium - trojrožec (znázorněno na obr. na s. 52, bez názvu taxonu) a rod Euglena (krásnoočko) zařazuje Kalina a Váňa (2005) do říše Prvoci (Protozoa), Adl et al. (2012) řadí Ceratium do Alveolata skupiny SAR, krásnoočko do skupiny Excavata. Je nutno podotknout, že učebnice je z roku 1999, a tudíž v ní moderní změny v systematice řas nemohou být zachyceny. 
- Řasy jsou v učebnici řazeny do oddělení pojmenovaného Nižší rostliny, což neodpovídá systematickému řazení řas podle Kaliny a Váni (2005). Nižší rostliny byly dříve na úrovni podř́íše a zahrnovaly kromě řas také houby a lišejníky (např. Rosypal et al., 1992). Toto systematické třídění organismů se ale již dlouhou dobu nepoužívá (viz Cavalier-Smith, 1981).

\section{DALŠÍ ODBORNÉ NEDOSTATKY}

\section{A NESPRÁVNÝ ODBORNÝ TERMÍN}

- U váleče je uvedeno, že se jedná o kolonii (s. 52, 53). Přesněji jde ale o cenobium. Komentář viz výše u podkategorie $2 \mathrm{~A}$ v textu k učebnici Čabradové et al. (2003) na s. 1-2 př́lohy.

\section{B NESPRÁVNÉ TVRZENÍ}

- Do kapitoly (oddělení) o jednobuněčných řasách autoři (na s. 52) umístili obrázek vláknité jařmatky (rod Zygnema), jejíž stélka je mnohobuněčná.

\section{C NEÚPLNÝ VÝČET}

- Jako jedna ze zajímavostí je v učebnici uvedena skutečnost (s. 53), že na území Arktidy a Antarktidy zbarvují řasy často do červena či zelena sníh i ledovce. Řasy však zbarvují sníh a led i v jiných částech světa, i v České republice v Krkonoších a na Šumavě (např. Nedbalová \& Lukavský, 2007; Lukavský, 2014).

\section{D NEPŘESNOST}

- V textu na s. 52 autoři uvádějí, že řasám vděčíme za atmosféru Země. Je tím myšlena zřejmě kyslíkatá atmosféra - tedy produkce kyslíku řasami - v geologické minulosti Země. Toto tvrzení však není zcela správné. Prvotní atmosféra se na Zemi vytvářela před 4,0-3,8 miliardami let, ta byla bezkyslíkatá (Víden, 2005). Prvními organismy, které Zemi přinesly fotosyntézu, byly sinice - zhruba před 2,5 mld. let (Šmarda, 2009; Vrtiška, 2014). Odpadním produktem fotosyntézy byl volný kyslík (Vrtiška, 2014). Podle Vrtišky (2014) v atmosféře rychle reagoval a před 2,3 mld. let začala jeho koncentrace $\mathrm{v}$ atmosféře stoupat. Za kyslíkatou atmosféru na Zemi vděčíme tedy spíše sinicím než řasám.

- Na s. 52 v postranní liště dole je návod, jak je možné si ověrit, že existují i hnědé řasy. Žáci si mají pod mikroskopem prohlédnout „přinesený vzorek rybniční vody“ (nebo ve vodě rozmíchaný vzorek seškrábnutého slizu z ponořeného dřeva, kamene atp.), naleznou zde schránky rozsivek. V přineseném vzorku rybniční vody bez předchozího zahuštění však žáci rozhodně nebudou schopni rozsivky pozorovat, v planktonu stojatých vod jich nebude dostatek pro přímé pozorování vody. Výskyt je také závislý na ročním období, v létě žáci zaznamenají spíše zelené planktonní řasy, na jaře jiné skupiny řas, téměř vždy je ale potřeba vzorek předem zahustit centrifugací (snad jen v silně zeleném rybníce to nebude třeba nebo $\mathrm{v}$ případě vodního květu tvořeného převážně sinicemi). Pro zisk rozsivek by doporučení mělo směřovat spíš na tekoucí vody (i když 
stěr z kamene či vegetace v rybníce je také možný, tak jak učebnice uvádí provést stěr z kamene nebo dřeva, a nejlépe bude upozornit na stěr hnědavého povlaku nebo „hnědého slizu“. Setřený materiál ve vodě už nerozmíchávat, ale př́mo ho dát na podložní sklo a mikroskopovat.

- Autoři řadí zelenivku, zrněnku, krásnoočko a váleč koulivý k „nejznámějším jednobuněčným zeleným řasám“ (s. 53). Není ale jasné, proč by měly být tyto čtyři taxony nejznámější a proč byly vybrány do učebnice. Zelenivka žije ve vodě i v půdě ( $u$ jejího popisu ovšem není tento výskyt vůbec zmiňován), je poměrně hojná, ale ve vzorcích vody algology často přehlížená, špatně určitelná. K nejhojnějším řasám našich vod ale rozhodně nepatří. Veřejnost ji v posledních letech zná pod jménem Chlorella jako potravinový doplněk, to ale v informacích o ní není uvedeno. Zrněnka je řasa hojná na kưře stromů (což v učebnici není uvedeno), je to u nás hojná řasa, je makroskopicky pozorovatelná. Krásnoočko je hojné v eutrofních vodách, váleč nepatří jako rod u nás k hojně se vyskytujícím řasám (navíc hojnější je váleč zlatý Volvox aureus - viz Kalina \& Váňa, 2005).

\section{E OSTATNí}

- Stélky řas v učebnici na s. 52 rozlišují autoři na jednobuněčné, vícebuněčné, vláknité. Toto sdělení není zcela srozumitelné. Vláknitá stélka je vlastně vícebuněčná. (Na stejné straně v textu výše je ještě navíc pojem mnohobuněčná stélka.)

\section{UČEBNICE P̌ríRODOPISU Z NAKLADATELSTVÍ NovÁ ŠKOLA (HEDBÁVNÁ, 2008)}

Hedbávná, H. (2008). Př́rodopis 2. díl: Botanika. Brno: Nová škola.

\section{NEDOSTATKY SPOJENÉ SE SYSTEMATICKÝM ZAŘAZENÍM ŘAS}

\section{A SYSTÉM/ROSTLINY}

- V rozšiřujícím textu kapitoly 2. třídění rostlin na s. 7 je uvedeno, že kromě zelených řas existují i řasy hnědé a červené. Autoři už ale neuvádí, že hnědé řasy mezi rostliny nepatř́. Hnědé řasy (zde jmenované chaluhy a rozsivky) Kalina a Váňa (2005) řadí do říše Chromista, Adl at al. (2012) do Stramenopila skupiny SAR.

- Na s. 77 jsou všechny skupiny řas (zelené, červené a hnědé) v závěrečném opakovacím textu opět řazeny do rostlin, hnědé řasy však do říše Plantae (rostliny) nepatří.

\section{DALŠÍ ODBORNÉ NEDOSTATKY}

\section{A NESPRÁVNÝ ODBORNÝ TERMÍN}

- U váleče je uvedeno, že se jedná o kolonii. Přesněji jde ale o cenobium. Komentář viz výše u podkategorie $2 \mathrm{~A}$ v textu k učebnici Čabradové et al. (2003) na str. 1-2 přílohy. 
- V kapitole 2 Moře a oceány na s. 77 je uvedeno tvrzení „mnohobuněčné řasy koření na dně a rostou hlavně u pobřeží. Na mysli autoři mají řasy moří a oceánů, což vyplývá z kontextu a názvu kapitoly. Řasy mají stélku, nemají tedy kořeny a výraz „koření na dně“ není vhodně zvolen. Možná by bylo vhodnější použít výrazu - jsou přichyceny/upevněny na dně. Mnoho mořských řas ani nemá rhizoidy a jsou přichyceny $\mathrm{k}$ podkladu např. pomocí bazální buňky či terčovité báze (např. mořské druhy rodu Cladophora, rod Fucus aj.; Kalina \& Váňa, 2005). Existují však i druhy řas, které jsou planktonní, v mořské vodě se vznášejí a u dna přichycené vůbec nežijí (např. některé druhy rodu Sargassum). Takový způsob života však autoři v učebnici vůbec neuvedli.

\section{C NEÚPLNÝ VÝČET}

- V textu o významu řas na s. 7 autoři uvádějí, že jsou součástí planktonu, který je zdrojem potravy pro živočichy. Text ale může působit dojmem, jako by řasy jinde než v planktonu nežily.

\section{UČEBNICE PříRODOPISU Z NAKLADATELSTVÍ Prodos (JuRČÁK \& FronĚK, 2004)}

Jurčák, J. \& Froněk, J. (2004). Přírodopis 6. Olomouc: Prodos.

\section{NEDOSTATKY SPOJENÉ SE SYSTEMATICKÝM ZAŘAZENÍM ŘAS}

\section{A SYSTÉM/ROSTLINY}

- Do kapitoly Jednobuněčné rostliny jsou řazena krásnoočka (rod Euglena), která patří dle Kaliny a Váni (2005) do ř́ŕše Protozoa (Prvoci), Adl et al. (2012) je řadí do skupiny Excavata společně s jinými prvoky.

- Na s. 20 jsou rozsivky zařazeny do kapitoly Jednobuněčné rostliny a také nazývány mikroskopickými rostlinami. Rozsivky ale Kalina a Váňa (2005) řadí do ř́ı̌e Chromista nikoli do říše Plantae. Adl et al. (2012) je řadí do Stramenopila skupiny SAR, nikoli do skupiny Archeplastida (kam řadí rostliny).

\section{$1 \mathrm{C}$ NIŽŠÍ ROSTLINY}

- Na s. 35 je uveden pojem nižší rostliny. Nižší rostliny byly dříve na úrovni podříše a zahrnovaly kromě řas také houby a lišejníky (např. Rosypal et al., 1992). Toto systematické tř́ídění organismů se ale již mnoho let nepoužívá (viz Cavalier-Smith, 1981).

\section{D SINICE/ROSTLINY}

- Do kapitoly Jednobuněčné rostliny (s. 16) a kapitoly Rostliny mnohobuněčné (s. 35) jsou spolu s řasami řazeny také sinice. To pokládají autorky za hrubou chybu. Sinice patří do říše Bacteria (Kalina \& Váňa, 2005). Autoři uvádějí příbuznost sinic s bakteriemi hned $\mathrm{v}$ první větě kapitoly Jednobuněčné rostliny (ale přesně - sinice jsou fotosyntetizující bakterie, nelze uvádět příbuznost 
s bakteriemi), přesto řazení sinic mezi rostliny ponechali. Bakterie jsou prokaryotické organismy, rostliny organismy eukaryotické, tedy organismy s naprosto rozdílnou stavbou buňky.

\section{DALŠÍ ODBORNÉ NEDOSTATKY}

\section{A NESPRÁVNÝ ODBORNÝ TERMÍN}

- V textu na s. 16 se uvádí, že „sinice mají v buňkách dutinky (vakuoly) naplněné dusíkem, takže se vznášejí (plavou) u hladiny“. Domníváme se, že aerotopy v buňkách sinic není možné nazývat vakuolami ani dutinkami. Správné označení pro tyto útvary je bud' plynové měchýřky, nebo aerotopy, do kterých se tyto měchýřky sdružují (Kalina \& Váňa, 2005).

- U váleče je v učebnici uvedeno, že tvoří kolonii (s. 20). Váleč ale přesněji tvoří tzv. cenobium. Vysvětlení viz s. 1-2 př́lohy, u učebnice Čabradové et al. (2003).

- V rozmnožování kadeřnatky (rod Ulothrix) na s. 36 jsou také nepřesnosti. Po pohlavním rozmnožování vznikne zygospora (kterou by snad bylo možné nazvat výtrusem, jak je na obrázku). Jedná se ale jen o jednu buňku - na obrázku je pojmenování výtrusy u 4 buněk vzniklých dělením zygospóry. Tyto buňky by se už výtrusy nazývat neměly. Na schématu je naznačeno i nepohlavní rozmnožování, které probíhá tvorbou tzv. zoidů se 4 bičíky (Kalina \& Váňa, 2005), ale není vůbec popsáno.

\section{B NESPRÁVNÉ TVRZENÍ}

- Na s. 16 se uvádí „Sinice mají v buňkách dutinky (vakuoly) naplněné dusíkem, takže se vznášejí (plavou) u hladiny". Tyto měchýřky ve skutečnosti nejsou naplněné jen dusíkem, ale směsí plynů rozpuštěných ve vodě (Kalina \& Váňa, 2005).

- Tvrzení (s. 17), že některé sinice obsahují v buňkách červené barvivo, je třeba poopravit, všechny sinice obsahují ve svých buňkách červené barvivo, a to fykoerytrin, který je součástí fykobilizomů.

- S následujícím tvrzením o sinicích „zajímavé je, že žijí nejen v mořích, ale mohou se vyskytovat i na sněhu, který potom má červenou barvu“, však nelze zcela souhlasit. Červená barva sněhových polí bývá většinou zpo̊sobena často řasou Chlamydomonas nivalis př́padně několika málo jinými druhy rodu Chlamydomonas (viz Ettl, 1983), jejíž červené zbarvení způsobují karotenoidy. Nicméně existují i druhy sinic, které žijí ve sněhu Arktidy i Antarktidy (Šmarda, 2009). Kalina a Váňa (2005) uvádí, že sinice rostou též mezi krystalky ledu na ledovém štítu Grónska a jsou primárními kolonizátory ledovcových morén.

- Na bázi potravní pyramidy na s. 17 jsou obrázky čtyř rodů řas (Micrasterias, snad krásivka Netrium, Phacus a zřejmě Spirogyra (je špatně znázorněná, je z ní vidět jen šroubovitý chloroplast, ale buněčná stěna na obrysu buněk chybí) a obrázek zřejmě nějaké vláknité sinice. $\mathrm{V}$ textu $\mathrm{k}$ tomuto patru pyramidy je uvedeno „1. patro: jednoduché řasy (zrněnka, šroubatka, pláštěnka) a sinice“. Zrněnka (Apathococcus) a pláštěnka (Chlamydomonas) však na obrázcích vůbec znázorněny nejsou. Navíc nálevníci - ve druhém patře potravní pyramidy (hned nad řasami) - se rozhodně šroubatkou ani vláknitou sinicí, vzhledem k jejich stélce, živit nebudou. Perloočky a bochnatky (3. patro pyramidy) se živí také fytoplanktonem a ne jen nálevníky, jak ukazuje potravní pyramida. 
- Na s. 17 vpravo dole jsou obrázky zřejmě dvou druhů krásnooček, obrázek rodu Chlamydomonas (pláštěnka) a obrázek řasy, kterou autorky nejsou schopny rozpoznat. K obrázku je uveden text: „bičíkovci a řasa zelenivka ve vodním prostředí“. Zelenivka (Chlorella) však na obrázku vůbec není.

- Na s. 18 je schéma krásnoočka štíhlého a jeho popis. V popisu autoři uvádějí, že krásnoočko štíhlé má 1-2 bičíky. Tato informace je silně zavádějící. Zástupci rodu Euglena (krásnoočko) mají viditelný jen jeden bičík (Cyrus \& Hindák 1978). Přesněji - k pohybu krásnoočku slouží ,jediný bičík vystupující z buňky, druhý je zakrnělý" (Kalina \& Váňa, 2005: s. 110).

- Tvrzení „sinice žijí i v úzké symbióze s houbami“ (s. 16) je také zavádějící. Lépe snad „některé sinice žijí i v úzké symbióze s houbami“.

- Na obrázcích sinic v rámečku na s. 16 dole je nepřesnost. Vpravo nahoře je kresba vláknité sinice s pojmenováním sinice řetízková s výtrusy. Zřejmě autoři měli na mysli akinety, což jsou podle Kaliny a Váni (2005) spory, které zajištují přezimování druhů sinic. V Kalinovi (2005) je též označení arthrospory. Podle Kaštovského a Hauera (2017b) slouží akinety k přečkání nepříznivého období, ale jako spory je neoznačují. Stejní autoři o akinetách uvádějí, že „lze je najít označené i archaickým názvem arthrospory".

- Součástí podkapitoly Bičíkovci jsou popisy stavby těla, fotosyntézy a dýchání řasy zrněnky (s. 19), která ale mezi bičíkovce nepatří.

- V podkapitole Rozsivky (s. 20) se hned na začátku uvádí, že „součástí planktonu jsou další mikroskopické rostliny - rozsivky. Tvoří slizovité povlaky na kamenech na dně vod." Planktonní rozsivky, vznášející se ve volné vodě (pelagiálu), netvoří slizovité povlaky na kamenech. Pokud to autoři mysleli tak, že rozsivky žijí v planktonu a na kamenech, pak je to správně.

- Na s. 20 dole je tvrzení „rozsivky většinou nejsou potravou jiným organismům“ velmi nepřesné. Rozsivky, podobně jako jiné řasy, slouží jako potrava organismům v dalším stupni potravního řetězce (např. Granéli \& Turner, 2002; Knox, 2000). Sama autorka (B. Brabcová) pozorovala mnohokrát pod mikroskopem nálevníky, kteří mají v sobě pozřelou rozsivku (šla by i podle schránky určit). Rovněž organismy živící se planktonem zcela jistě pozřou také planktonní rozsivky. Vždyt např. v mořích patří rozsivky k hlavním primárním producentům (Kaštovský \& Hauer, 2017c).

- Na s. 35 autoři uvádí, že šroubatka se rozmnožuje na podzim za nepříznivých podmínek. Pohlavně rozmnožovat se může šroubatka ale i v jiném ročním období, nejen na podzim, pokud dojde ke změně podmínek směrem k nepříznivým (zkušenosti autorky B. Brabcové, P. Marvan - ústní sdělení). V textu je také uvedeno, že se jedná o náznak pohlavního rozmnožování. Odborníci však tento způsob řadí přímo mezi pohlavní rozmnožování (Kalina \& Váňa, 2005).

\section{C NEÚPLNÝ VÝČET}

- Na s. 16 autoři uvádějí, že se za příznivých podmínek mnoho sinic vyskytuje při hladině stojatých vod, a že „spolu s jinými mikroskopickými rostlinami, zvláště řasami, tvoří společenstvo organismů nazývané rostlinný plankton". Takto to vypadá, že plankton se vyskytuje jen u hladiny stojatých vod. Vodní květ sinic ano, ale fotosyntetizující planktonní organismy (fytoplankton) se vyskytuje ve stojaté vodě až do určité hloubky v závislosti na světelných i jiných podmínkách prostředí. 
- Zelenivka (s. 21) je nejen součástí planktonu, jak autoři uvádějí, ale vyskytuje se též v půdě, na skalách. V půdě je zelenivka hojnou řasou.

\section{D NEPřESNOST}

- Průřez kolonií sinic na jednom z obrázků (s. 16, vpravo dole) je nejasný i pro odborníka. Není jasné, kolonii jakých sinic měli autoři na mysli. Text o sinicích se navíc o koloniích sinic vůbec nezmiňuje.

- Na s. 20 je mezi kresby rozsivek s označením „různé druhy rozsivek“ zařazena auxospóra rodu Melosira, což není vhodné. Auxospóra je výsledkem pohlavního rozmnožování a vypadá jinak, než vegetativní stélka rozsivky. Vlevo nahoře je perokresba, která nepřipomíná žádnou běžně se vyskytující rozsivku. Leda snad nějakou centrickou mořskou, ale ty výběžky se zdají být příliš pravidelné a ještě navíc rozdvojené, což u mořské rozsivky nelze očekávat. Kresba spíše připomíná dírkonošce s panožkami.

- V kolonii váleče na obrázku na s. 20 nejsou správně zakreslena dceřiná cenobia. Ze začátku jsou dceřiná cenobia skutečně obrácena dovnitř mateřského cenobia, ale jsou umístěna „těsně pod povrchem“ (Kalina \& Váňa, 2005: s. 469, obr. 235), později se vychlípí směrem ven a mateřské cenobium opustí.

\section{E OSTATNÍ}

- Porovnávat (s. 21) zrněnku a krásnoočko není vhodné. Tyto dva organismy patří každý do jiné říše organismů. Ani tvarem zrněnka krásnoočko nepřipomíná.

\section{UČEBNICE P̌̌́íRODOPISU Z NAKLADATELSTVÍ ForTUNA (KVASNiČKOVÁ ET AL., 2002)}

Kvasničková, D., Jeník, J., Pecina, P., Froněk, J. \& Cais, J. (2002). Ekologický př́rodopis pro 6. ročník základní školy a nižši ročníky víceletých gymnázií. Praha: Fortuna.

Vzhledem k tomu, že v této učebnici nejsou organismy členěné podle jejich zařazení v systému organismů, ale podle ekologických souvislostí, jsou řasy probírány v podkapitole Rostliny a houby našich lesů (s. 8, 10-11) kapitoly Les a v podkapitole Rostliny rybníka a jeho okolí (s. 68-75) kapitoly Rybník.

\section{NEDOSTATKY SPOJENÉ SE SYSTEMATICKÝM ZAŘAZENÍM ŘAS}

\section{A SYSTÉM/ROSTLINY}

- V podkapitole Rostliny a houby našich lesů jsou zmiňovány pouze dva rody řas a oba patř́i do říše Plantae (Rostliny), do podkapitoly Rostliny rybníka a jeho okolí je zařazeno i krásnoočko štíhlé (s. 74), které do říše Plantae nepatří. Kalina a Váňa (2005) ho řadí do ř́šse Protozoa (Prvoci), Adl et al. (2012) do skupiny Excavata (rostliny podle Adla et al. (2002) patř́ do skupiny Archeplastida).

- Na obr. 118 (s. 75) jsou pod označením „a rostlinnou částí planktonu jsou různé řasy - a, b“ uvedeny kresby mimo jiné rodů Ceratium a Euglena, které nepatří mezi rostliny, oba rody řadí Kalina a Váňa (2005) do ř́íše Protozoa (Prvoci), 
Adl et al. (2012) pak Ceratium do Alveolata skupiny SAR, Euglenu do sk. Excavata.

\section{DALŠÍ ODBORNÉ NEDOSTATKY}

\section{A NESPRÁVNÝ ODBORNÝ TERMÍN}

- Na s. 74 je uvedeno, že váleč má kolonii. Přesněji ale váleč tvoří tzv. cenobium. Vysvětlení viz u učebnice Čabradové et al. (2003), s. 1-2 přílohy.

\section{B NESPRÁVNÉ TVRZENÍ}

- Na obr. 118 Sladkovodní plankton (s. 75) je kresba vláknité větvené řasy pravděpodobně rodu Cladophora (žabí vlas) nebo Stigeoclonium. Řasa s takovou stélkou a ani žádný z těchto rodi̊ nežije planktonním způsobem života. Vláknité větvené řasy většinou žijí přichycené bazální buňkou k podkladu.

\section{C NEÚPLNÝ VÝČET}

- V podkapitole Rostliny rybníka a jeho okolí je na s. 74 uveden výrok „řasy a sinice se bud' vznášejí ve vodě, nebo pokrývají listy rostlin“. Řasy v prostředí rybníka však žijí na různých podkladech, nejen na listech.

\section{D NEPřESNOST}

- Na s. 11 se uvádí, že „podobně jako zrněnka žijí v lesích i další řasy. Některé mají tělo složitější, má větší počet buněk obvykle spojených do vláken. Takovým rostlinám ř́káme mnohobuněčné." Nad tímto textem je obr. 9 s označením "Vláknitá zelená řasa šroubatka“. Tyto informace navádějí k tomu, že by šroubatka mohla žít podobně jako zrněnka, to ovšem neodpovídá skutečnosti. Zatímco zrněnka žije převážně na kưře stromů, šroubatka žije naopak ve sladkých stojatých i tekoucích vodách, v lese ji najdeme jen málokdy, snad na nějakých dobře osvětlených místech - v př́kopech, zaplavených proláklinách či úživných potocích. Nežije však podobně jako zrněnka na kůře stromů.

\section{UČEBNiCE P̌̌íROdOPISU Z NAKLADATELSTVÍ ČESKÉ GEOGRAFICKÉ SPOLEČNOSTI (MALENINSKÝ ET AL., 2004)}

Maleninský, M., Smrž, J. \& Škoda, B. (2004). Přírodopis pro 6. ročník, Botanika 1, Zoologie 1. Praha: Nakladatelství České geografické společnosti.

\section{NEDOSTATKY SPOJENÉ SE SYSTEMATICKÝM ZǍ̌AZENÍM ŘAS}

\section{A SYSTÉM/ROSTLINY}

- O všech řasách se ve výukovém textu mluví jako o rostlinách (přímo pak např. s. 24 sloupec vlevo nahoře, s. 26 text nahoře u kresby). V učebnici jsou však zahrnuty i řasy, které do rostlin nepatří. Krásnoočko (s. 23) řadí Kalina a Váňa (2005) mezi prvoky (Protozoa), Adl et al. (2012) do skupiny Excavata. Je dobře, 
že autoři ale v textu zdo̊raznili (s. 23), že krásnoočko „stojí na pomezí rostlinné a živočišné ř́še". Hnědé řasy - v učebnici rozsivky a chaluhy - řadí Kalina a Váňa (2005) do říše Chromista, Adl et al. (2012) do skupiny Stramenopila z tzv. SAR skupiny.

\section{DALŠÍ ODBORNÉ NEDOSTATKY}

\section{A NESPRÁVNÝ ODBORNÝ TERMÍN}

- Rozdíl mezi cenobiem a kolonií u váleče (a v př́ípadě této učebnice se to týká též rodu Scenedesmus - řetízovka) je popisován již u publikace Čabradové et al. (2003) na s. 1-2 př́lohy.

\section{B NESPRÁVNÉ TVRZENÍ}

- Tvrzení na s. 23 „takový vesnický rybník s brčálově zelenou vodou je jistě plný zelenivek" nejspíš nebude pravdivé. Pravděpodobnější přičinou zeleného zbarvení vody jsou bud' zelené kokální nebo cenobiální řasy, př́padně krásnoočka. Tedy hlavně zástupci rodů Chlamydomonas, Scenedesmus, Pediastrum nebo rodu Euglena. V př́padě zeleného povlaku na hladině by se jednalo o vodní květ sinic. Zelenivka (rod Chlorella) je drobná kokální řasa (většina zelenivek je půdních) a bývá algology ve vzorcích $z$ vody asi často přehlížena, přesto si autorka (B. Brabcová) myslí, že nebývá v planktonních vzorcích rybniční vody tak hojná.

- Podobně na s. 22 se zelenivky týká tvrzení „,jednou z nejhojnějších řas v rybnících, řekách a kalužích je zelenivka“. Ani tady bychom s tímto tvrzením spíše nesouhlasily. Zvláště v řekách je celá řada jiných řas, po mnohaletých zkušenostech B. Brabcové myslíme, že hojnějších.

- Text na s. 24 „nejmenší ze zelených řas jsou jednobuněční bičíkovci“ představuje sporné, těžko ověřitelné tvrzení. Je pravděpodobné, že některé kokální zelené řasy jsou ještě menší/drobnější než bičíkovci.

\section{C NEÚPLNÝ VÝČET}

- Text k fotografii na s. 23, kde se uvádí, že „zelený zákal vody v tomto zanedbaném akváriu s nadbytkem světla je způsobený zelenivkami" nebude asi úplně vyčerpávající. Spíš barva bude zpơsobena také jinými druhy řas a také ovlivněna nárostovými řasami na stěnách akvária. Bohužel, až na s. 24 (ne tedy př́mo u popisu zelenivky), je zmiňován výskyt této řasy také na vlhkých místech souše, přitom většina druhů je právě půdních (Kaštovský \& Hauer, 2017d).

\section{D NEPŘESNOST}

- Zrněnka na obrázku na s. 28 neodpovídá přesně skutečnosti - často se buňky zrněnky vyskytují ve shlucích, a tak jsou taky pod mikroskopem pozorovatelné (pravda je, že ne všechny buňky ale ve shlucích jsou, a tento obrázek nepředstavuje objekt pozorovaný v mikroskopu, ale v podstatě schéma). 


\section{UČEBNICE Př́́RODOPISU Z NAKLADATELSTVÍ NovÁ ŠKOLA (MUSILOVÁ \& KonĚTOPSKÝ, 2007)}

Musilová, E. \& Konětopský, A. (2007). Přírodopis 1. díl: Úvod do učiva přírodopisu. Brno: Nová škola.

\section{NEDOSTATKY SPOJENÉ SE SYSTEMATICKÝM ZAŘAZENÍM ŘAS}

\section{A SYSTÉM/ROSTLINY}

- Všechny jednobuněčné řasy jsou označovány jako rostliny, včetně rozsivek, které do říše Plantae (rostliny) nepatř́i. Kalina a Váňa (2005) je řadí do říše Chromista, Adl et al. (2012) do skupiny Stramenopila z tzv. SAR skupiny.

\section{DALŠÍ ODBORNÉ NEDOSTATKY}

\section{B NESPRÁVNÉ TVRZENÍ}

- Na s. 46 je uvedeno, že „ve vlhké půdě nebo ve sladké vodě se vyskytují jednobuněčné řasy zelenivka a pláštěnka“. Zelenivka (Chlorella) má opravdu druhy sladkovodní i půdní, ale rod pláštěnka (Chlamydomonas) má většinu druhů sladkovodních (několik set druhů, viz Ettl, 1983), několik málo druhů mořských a salinních (Ettl, 1983, uvádí 18 druhů), některé její druhy žijí i na sněžných polích (Ettl, 1983, uvádí 5 druhů), pláštěnky žijící v půdě však žádné Ettl (1983) ve svém kompendiu a zelených bičíkatých řasách neuvádí.

\section{C NEÚPLNÝ VÝČET}

- Na s. 46 žáky informují, že jednobuněčné řasy jsou součástí planktonu. Dokonce uvádějí „ve vodě se řasy většinou volně vznášejí, podobně jako někteří drobní živočichové". Toto tvrzení je ale zavádějící. Mnoho druhů řas o poměrně velké biomase žije ve vodě nejen planktonním způsobem života, ale také přichycených na různých podkladech.

\section{D NEPŘESNOST}

- Pokud budou žáci mikroskopovat řasu zrněnku (návod je uveden na s. 46), neuvidí pravděpodobně pod mikroskopem jen „drobné kulovité útvary řasy zrněnky“ (proč není uvedeno buňky, nebo se těmito útvary buňky nemyslí?) jak uvádí návod. Jednotlivé buňky totiž často tvoří shluky či krátká vlákna.

- V návodu na pozorování vodních řas pod mikroskopem (s. 46) je uvedeno, že se má nabrat nazelenalá voda. To ovšem neznamená, že v kapce této vody pod mikroskopem řasy uvidí. Většinou je třeba vodu zahustit centrifugací a teprve kapku sedimentu pozorovat pod mikroskopem. (V prŕpadě silného rozvoje vodního květu pak při odebrání vody z hladiny budou sinice $\mathrm{v}$ kapce vody pozorovatelné, ale sinice vodního květu produkují toxiny a odběr holou rukou do lahvičky žákům nelze doporučit. Navíc v návodu se hovoří o řasách.) Při zachycení řas $\mathrm{v}$ kapce vody také hraje roli místo a čas odběru. Pro úspěch (zachycení řas z kapky vody bez zahuštění) je třeba provádět odběr v letním období z rybníka bohatého na živiny, u kterého se v létě rozvine bohatý fytoplankton. Z vody „kaluže“, jak autoři uvádějí, zřejmě bude úspěch zachycení 
řas velmi nízký. Záleží na typu kaluže, přetrvávající kaluž na luční/polní cestě nebo voda př́kopu řasy obsahovat bude, ovšem spíš než volnou vodu by bylo lépe nabrat nějaký zelený povlak ze dna kaluže.

BLAŽENA BRABCOVÁ, brabcova@ped.muni.cz

LIBUŠE VodovÁ, vodova@ped.muni.cz

KATEŘINA HvĚZDOVÁ, 371241@mail.muni.cz

Masarykova univerzita, Pedagogická fakulta

Katedra biologie

Poříčí 7/9, 60300 Brno, Česká republika 